\title{
Whose Landscape Is It? Remapping Memory and History in Interwar Central Europe
}

\author{
Nóra Veszprémi \\ Department of Art History, Masaryk University, Brno, Czechia \\ Email: veszpremi@phil.muni.cz
}

\begin{abstract}
After the collapse of the Habsburg Empire and the sanctioning of new national borders in 1920, the successor states faced the controversial task of reconceptualizing the idea of national territory. Images of historically significant landscapes played a crucial role in this process. Employing the concept of mental maps, this article explores how such images shaped the connections between place, memory, and landscape in Hungary and Czechoslovakia. Hungarian revisionist publications demonstrate how Hungarian nationalists visualized the organic integrity of "Greater Hungary," while also implicitly adapting historical memory to the new geopolitical situation. As a counterpoint, images of the Váh region produced in interwar Czechoslovakia reveal how an opposing political agenda gave rise to a different imagery, while drawing on shared cultural traditions from the imperial past. Finally, the case study of Dévény/Devín/Theben shows how the idea of being positioned "between East and West" lived on in overlapping but politically opposed mental maps in the interwar period. By examining the cracks and continuities in the picturesque landscape tradition after 1918, the article offers new insight into the similarities and differences of nation-building processes from the perspective of visual culture.
\end{abstract}

Keywords: landscape; Hungary; Czechoslovakia; revisionism; Trianon; mental maps; memory sudies; memory politics; picturesque

In 1932 the journalist and author Árpád Pásztor (1877-1940) took part in a cruise along the Danube and described his experiences in the Hungarian liberal daily Pesti Napló. As the ship passed the ruined castle of Devín, near Bratislava, Pásztor could not help but feel sentimental. Less than two decades earlier the area had still been part of Hungary, but in 1920 the Treaty of Trianon allocated it to Czechoslovakia. The political changes had transformed the landscape: "The rock on which the Árpád monument once stood emerges from the water bare and solemn. Where once the bronze Turul [mythical Hungarian bird] had spread its wings, now a flagpole stands high, but on the grassy side of the castle hill a group of children are playing merrily in the spring sunshine-today's children, tomorrow's adults, who no longer ruminate on yesterday."1

This brief passage is an eloquent example of how historical memories were inscribed into the landscape in interwar Central Europe. The text evokes past, present, and future, projecting all three onto the picturesque image of the Devín hill. The Austro-Hungarian past appears in the form of the

This article is part of a project that has received funding from the European Research Council (ERC) under the European Union's Horizon 2020 research and innovation program (Continuity/Rupture: Art and Architecture in Central Europe 19181939 [CRAACE], grant agreement No. 786314). I am grateful to the CRAACE research team: Matthew Rampley, Christian Drobe, Marta Filipová, and Julia Secklehner, as well as to colleagues from the Art History Department and the East Central Europe Research Forum of the University of Birmingham, and to the two peer reviewers for the Austrian History Yearbook for their helpful comments on previous versions of this article. Special thanks to Katarína Beňová and Michaela Hojdysz for their help with my research.

${ }^{1}$ Árpád Pásztor, “A cseh Dunán,” Pesti Napló, 3 June 1932, p. 4.

(c) The Author(s), 2021. Published by Cambridge University Press on behalf of the Center for Austrian Studies, University of Minnesota. This is an Open Access article, distributed under the terms of the Creative Commons Attribution-NonCommercial-NoDerivatives licence (http://creativecommons.org/licenses/by-nc-nd/4.0/), which permits non-commercial re-use, distribution, and reproduction in any medium, provided the original work is unaltered and is properly cited. The written permission of Cambridge University Press must be obtained for commercial re-use or in order to create a derivative work. 
monument erected by Hungarian authorities in 1896 to commemorate the one-thousandth anniversary of the conquest of the territory by Magyar tribes. The column had been toppled in 1921 and replaced by a flagpole with the Czechoslovak flag: the symbol of the present. Hence, Devín appears as a site of conflicting memory politics, but its beauty also compels Pásztor to imagine a bright future in which that conflict will be a thing of the past.

In a region where national borders had recently been radically redrawn, and where the status of certain territories was still fervently contested, the historical dimension of the landscape inevitably gained significance. Pásztor's way of thinking was, however, not new: his words echoed how place and history had been entangled in romantic travel literature for more than a hundred years. Countless travelers before him had drifted along rivers and recounted the histories of the sites they passed by, and these textual narratives were matched by paintings and prints that represented landscapes with details alluding to their past, present, and future. Indeed, in its suggestive visuality, Pásztor's passage almost sounds like a description of a landscape painting in the picturesque tradition. A central tenet of picturesque aesthetics was variety, and the way the text brings together past, present, and future; gloom and happiness; the serious history of adults and the lighthearted games of children satisfies this requirement eminently.

This article will explore the relationship between memory politics and images of landscapes in interwar Central Europe, focusing on Slovakia-formerly Northern Hungary, then part of Czechoslovakia-as a contested territory. As in the previously mentioned example, it will look for continuities, investigating how previous conceptual and visual frameworks were adapted to new political circumstances. It will, however, also stress the deep rupture after World War I. In Hungary, the politics of revisionism - the idea that the territorial decisions made at the peace conference should be revised in Hungary's favor-was promoted by the government and enjoyed wide public support. This had a profound impact on how people conceptualized the relationship between nation, place, and history. Pásztor's article is a case in point: while arguing for historical reconciliation and acceptance of the new borders, the author still viewed the Devín landscape as a symbol of regime change.

Far from being unique to Hungary, revisionism was present in all countries affected by the peace process. Its prevalence in interwar political thinking suggests that it was more than a set of geopolitical and strategic aims specific to each country. Although often diametrically opposed to each other, these aims rested on a shared premise: that certain geographical territories belonged to certain nations by natural and historical right. This idea was so deep-seated that-rather than just describing it as a consequence of ethnonationalism-it is possible to describe revisionism as an ideology in itself. As Holly Case has argued, the way revisionism permeated life on many different levels, from public to private and from state ceremonies to everyday acts, marks it out as more than just a political cause driven by the specific events of the time. ${ }^{2}$

In recent years, the focus of scholarship on Trianon and Hungarian revisionism has shifted from elite politics toward the exploration of these widespread mental frameworks. ${ }^{3}$ The groundwork was laid by Miklós Zeidler's in-depth examination of the everyday culture of revisionism. ${ }^{4}$ Balázs Ablonczy's book on "Trianon legends" shows how revisionism was disseminated by popular myths that suggested that Hungary had been treated unfairly in the peace negotiations. ${ }^{5}$ New primary sources have been made accessible to research, such as personal testimonies revealing how people from

\footnotetext{
${ }^{2}$ Holly Case, "Revisionism in Regional Perspective," in Territorial Revisionism and the Allies of Germany in the Second World War: Goals, Expectations, Practices, ed. Marina Cattaruzza, Stefan Dyroff, and Dieter Langewiesche (New York, 2012), 72-91. On revisionism in different European countries in the interwar period see the other essays in the same volume.

${ }^{3}$ For an authoritative discussion of the political history of Trianon see Ignác Romsics, The Dismantling of Historical Hungary: The Peace Treaty of Trianon, 1920 (New York, 2002). For a concise summary of the spectrum of revisionist aims see Romsics, "Hungarian Revisionism in Thought and Action, 1920-1941: Plans, Expectations, Reality," in Territorial Revisionism and the Allies of Germany in the Second World War, 92-101.

${ }^{4}$ Miklós Zeidler, A magyar irredenta kultusz a két világháború között (Budapest, 2002); Miklós Zeidler, Ideas on Territorial Revision in Hungary: 1920-1945 (Boulder, 2007). See also Miklós Zeidler, ed., Trianon (Budapest, 2003) and its two subsequent editions, a monumental collection of primary and secondary sources related to Trianon.

${ }^{5}$ Balázs Ablonczy, Trianon-legendák (Budapest, 2015).
} 
different walks of life thought about Trianon. ${ }^{6}$ The centenary of the treaty has resulted in increased scholarly attention on the subject. In addition to new volumes on various diplomatic aspects of Trianon, there has been pronounced interest in topics like "Trianon refugees" or the impact of regime change at a local level and on individual lives. ${ }^{7}$

This body of work illuminates how people's concepts of national territory and their own place in it were reshaped in the wake of the events of 1918-20. This process created new mental maps in which old connections between locations were broken and new connections forged, and the historical memories attached to these places were also subject to constant reinterpretation. Few scholars have engaged in depth with the role of visual imagery in this process: most notably Katalin Sinkó, whose study of the "body of the nation" as a site of memory has highlighted the connection between interwar anthropogeography, memory politics, and visual culture. ${ }^{8}$ Images of landscapes have not been discussed in this context so far, even though they played an important part in making mental maps more real and enhancing their emotional power.

To explore how they did so, this article will look at a range of images relating to several sites of memory. In the first two sections, it will examine two important revisionist publications, both of which employed landscapes in their visual rhetoric. The first, Bleeding Hungary, is a literary anthology illustrated by etchings depicting locations in the "lost" territories. Evaluated today as the highestquality product of revisionist literature, it was the earliest such publication aimed at the general public in Hungary and involved a range of prominent writers of diverse political persuasions. ${ }^{9}$ The second example, the richly illustrated album Justice for Hungary!, has been chosen because of its wide dissemination and influence: it was published in five languages and some of its imagery-most notably the picture of Greater Hungary crucified-became a standard part of the revisionist pictorial repertoire.

These publications employed landscape imagery to suggest that there is such a thing as "national territory," and that it could be delineated by taking stock of the most important vistas. This idea was not unique to Hungary: the second half of the article will show the overlaps between conflicting mental maps by comparing representations of some specific memory sites created from different national and political viewpoints. Examples are taken from Slovakia, not only because its territory is rich in such overlaps but also because of the robust nineteenth-century pictorial tradition attached to the places in question. Examining the cracks and continuities in this tradition after 1918, the article offers new insight into the similarities and differences of nation-building processes from the perspective of visual culture.

\section{Revisionist Mental Maps: Bleeding Hungary as a Blueprint}

Published in 1921, Bleeding Hungary (Vérzö Magyarország) was one of the first Hungarian revisionist books. $^{10}$ Offering a colorful collection of poems, short stories, and political-historical essays, the anthology promoted the idea that, due to their supposed cultural superiority, Hungarians had a natural right to rule over all other ethnic groups in the former territory of the Kingdom of Hungary. ${ }^{11}$ Edited by the brilliant poet and novelist Dezső Kosztolányi (1885-1936)-better known as a leading

\footnotetext{
${ }^{6}$ Gergely Kunt, Béni L. Balogh, and Anikó Schmidt, eds., Trianon arcai: Naplók, visszaemlékezések, levelek (Budapest, 2018).

${ }^{7}$ On Trianon refugees see István Dékány, Trianoni árvák (Budapest, 2018). Balázs Ablonczy’s new book Ismeretlen Trianon (Budapest, 2020) contains essays on both Trianon refugees and various aspects of local regime change. The large-scale research project NEPOSTRANS led by Gábor Egry at the Institute of Political History in Budapest examines local and regional transitions in Central Europe after 1918.

${ }^{8}$ Katalin Sinkó, "The Offended Hungária," in War of Memories: A Guide to Hungarian Memory Politics, ed. Dóra Hegyi, Zsuzsa László, and Zsóka Leposa (Budapest, 2015), 13-38.

${ }^{9}$ Zeidler, Ideas on Territorial Revision in Hungary, 221-22.

${ }^{10}$ Dezső Kosztolányi, ed., Vérző Magyarország: Magyar írók Magyarország területéért (Budapest, 1921).

${ }^{11}$ For a detailed examination of the book and its ideology see András Lengyel, “A 'Vérző Magyarország’: Kosztolányi Dezső irredenta antológiájáról,” Literatura 33, no. 4 (2007): 399-424. On Kosztolányi and revisionism see also Mihály Szegedy-Maszák, "Vérző Magyarország," Kalligram 19, no. 4 (2010): 83-96. On the second edition (Dezső Kosztolányi, ed., Vérző Magyarország: Magyar írók Magyarország területéért [Budapest, 1928]) see Tamás Bíró-Balogh, “A Vérző Magyarország második kiadása: Kosztolányi jelentősen átdolgozott' irredenta antológiája,” Kalligram 18, no. 11 (2009): 65-70. A new edition has been published for the centennial of Trianon: Dezső Kosztolányi, ed., Vérző Magyarország (Budapest, 2020).
} 


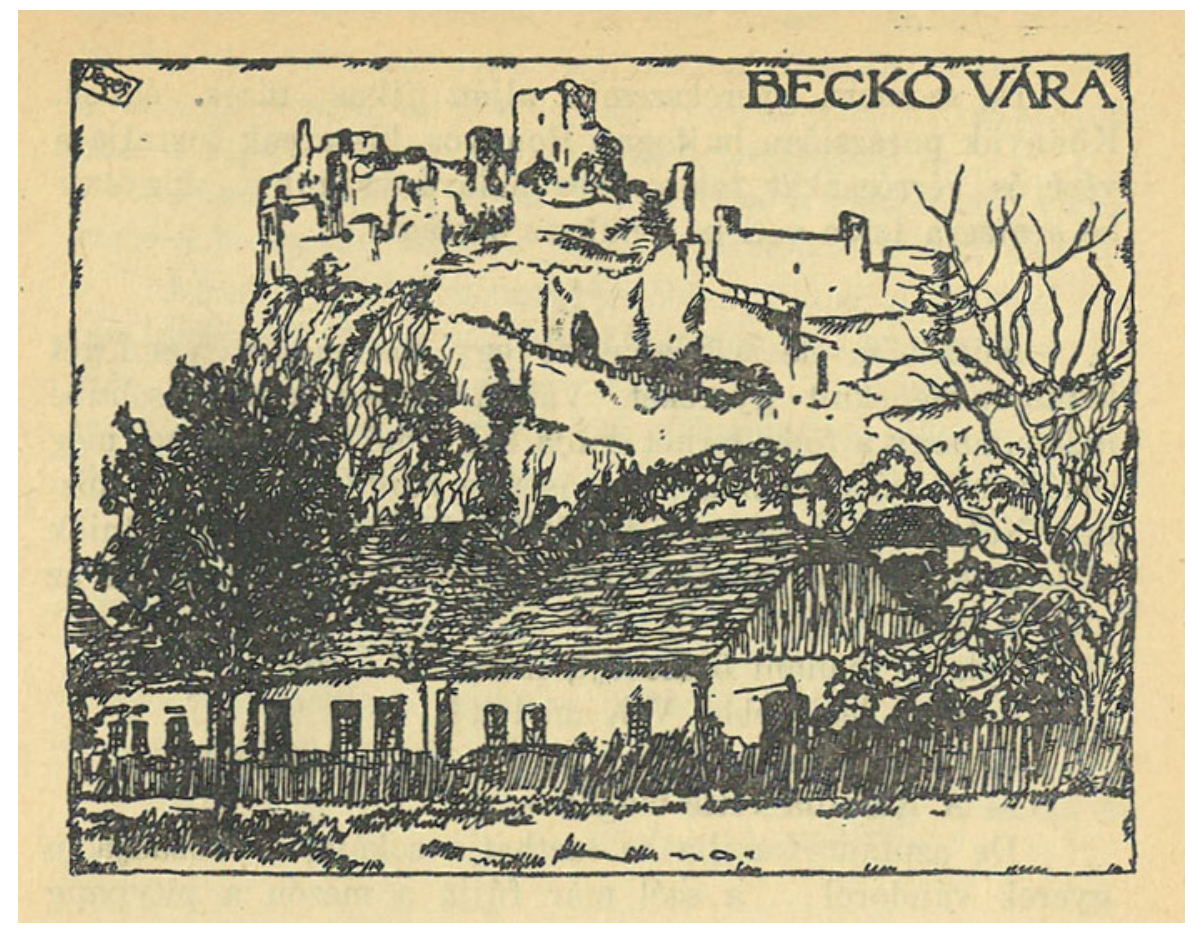

Figure 1: Ernő Jeges, The Castle of Beckó/Beckov/Betzko, illustration from the volume Vérző Magyarország: Magyar írók Magyarország területéért, ed. Dezső Kosztolányi (Budapest, 1921), 81. Photo: public domain.

contributor of the liberal modernist literary periodical Nyugat ("West")—and containing texts by many other luminaries of early twentieth-century literature, Bleeding Hungary is an uncomfortable reminder of the ubiquity of combative nationalism and revisionism in interwar Hungary. ${ }^{12}$ Politicians and other public figures also contributed; the introduction was written by Admiral Miklós Horthy (1868-1957), who had by then cemented his position as governor of Hungary, establishing the eponymous autocratic regime.

Bleeding Hungary was a highly diverse volume in terms of authors, genres, as well as the quality of contributions, but-to Kosztolányi's credit-it was very consciously and carefully structured. Like many anti-Trianon publications that came after it, the anthology aimed to make its message more tangible by anchoring it to actual physical spaces in the former kingdom-the area nostalgically referred to as "Greater Hungary" (Nagy-Magyarország). To this end, the young artist Ernő Jeges (1898-1956) was commissioned to create a series of illustrations showing locations in the regions now outside the borders (Figure 1). In addition, the book also contained a foldout map, which-in the manner of countless similar maps later created in interwar Hungary-showed the extent of the losses by embedding the new, small Hungary into the former larger kingdom (Figure 2). In the lost territories, the map highlighted the birthplaces of great personalities from Hungarian cultural history. The message was obvious, but it was also spelled out in words on the side of the page: all these great men (all men), undeniably Hungarian, had been born in these territories, which means that the territories are undeniably Hungarian too. Hungarian culture is organically spread out across the former kingdom; the new borders are just obstacles that disrupt its natural growth.

To understand how people in the past conceptualized the land they inhabited and the wider world around them, historians have recently been borrowing the concept of mental maps from cognitive

\footnotetext{
${ }^{12}$ Contributors included other writers from the circle of Nyugat (Árpád Tóth, Aladár Schöpflin, Frigyes Karinthy, Mihály Babits), as well as prominent conservative authors, such as Ferenc Herczeg (subsequently a leading figure of the revisionist movement), and some on the more extreme right, like Cécile Tormay and József Erdélyi.
} 


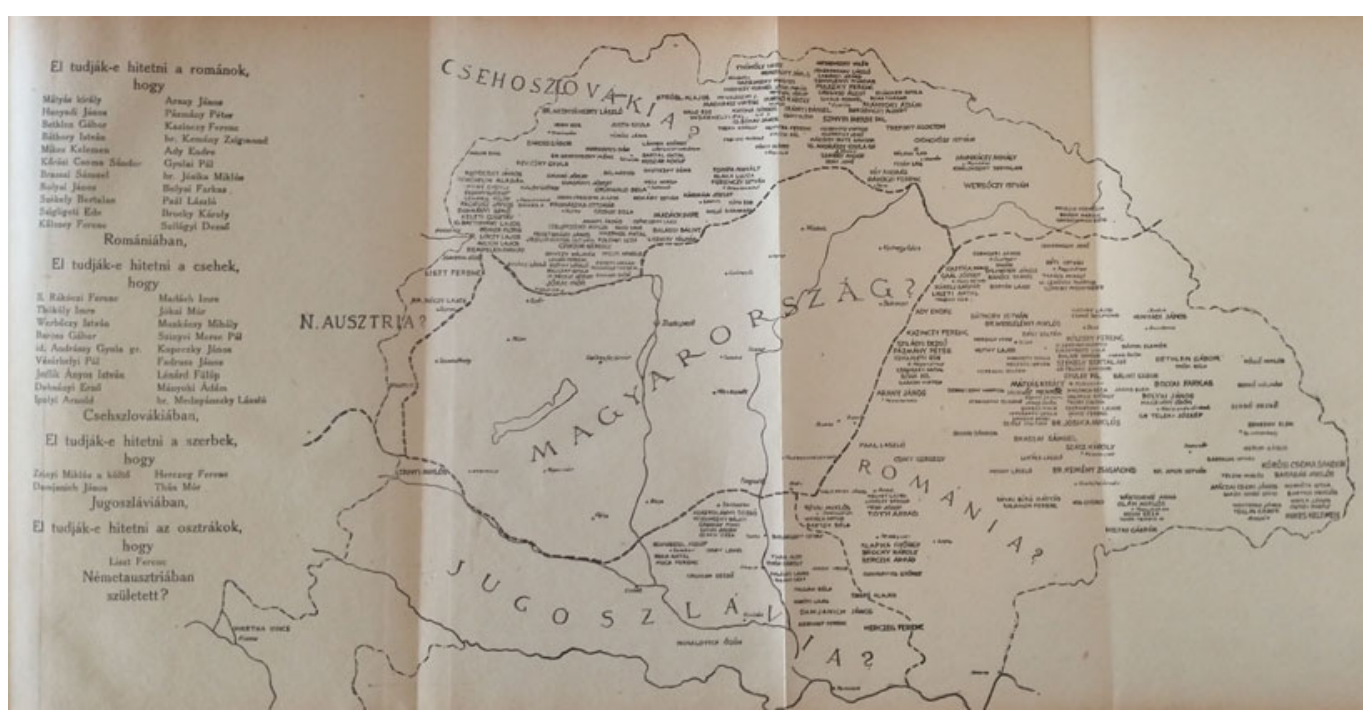

Figure 2: Map showing the birthplaces of famous Hungarians, illustration from Vérző Magyarország: Magyar írók Magyarország területéért. Photo: public domain.

psychology. Mental maps are not just mental images of the spatial layout of an area, learned and utilized by the human brain: they also assign values and meanings to specific locations. ${ }^{13}$ In mental maps, places are interesting because of the cultural, historical, or personal associations they evoke. Hence, their historical study explores "how personal concepts of space are influenced by (world)views which are transferred culturally, and how shared collective representations of an-experienced or imagined-spatial environment in turn affect processes of cultural group formation and identity formation." 14 The concept has proved particularly useful in the study of interwar Central Europe, where political borders drawn up after World War I were intersected in all directions by the mental maps of different national, ethnic, political, or social groups. ${ }^{15}$ The new geopolitical situation not only transformed people's mental maps but also gave rise to official and unofficial efforts to influence these transformations. Anti-Trianon propaganda produced in interwar Hungary is a revealing example.

The map published in Bleeding Hungary made it possible for readers to take an imaginary journey through the lost territories, visiting the birthplaces of great Hungarians. It was a blueprint for the mental map patriotic Hungarians were expected to interiorize: a guide to filling those lost territories with values and turning them into objects of nationalist nostalgia. The interplay between images and texts in the rest of the book serves the same purpose. Jeges's illustrations sometimes correspond to the texts alongside which they appeared and sometimes do not. At times, consecutive images depict locations in geographical proximity to each other, imitating a real journey, but other times they transport the reader in wild zigzags across the Carpathian Basin, from the north to Romania, then back, and then down to the Balkans. Some are landscapes, while many depict buildings: historical monuments whose purpose was, yet again, to attest to the prominence of Hungarian culture in these lands.

Ernő Jeges was born in 1898 in Torontálvásárhely/Debeljača. ${ }^{16}$ His artistic interests first manifested in printmaking, and in 1917 he moved to Budapest to study at the School of Applied Art. In 1918 he

\footnotetext{
${ }^{13}$ Frithjhof Benjamin Schenk, "Mental Maps: The Cognitive Mapping of the Continent as an Object of Research of European History," European History Online (EGO), 8 July 2013, http://www.ieg-ego.eu/schenkf-2013-en; Norbert Götz and Janne Holmén, "Introduction to the Theme Issue: Mental Maps: Geographical and Historical Perspectives," Journal of Cultural Geography 35, no. 2 (2018): 157-61.

${ }^{14}$ Schenk, "Mental Maps," 2.

${ }^{15}$ For examples of this approach in the study of interwar Central Europe see Steven Seegel, Map Men: Transnational Lives and Deaths of Geographers in the Making of East Central Europe (Chicago, 2018); Larry Wolff, Woodrow Wilson and the Reimagining of Eastern Europe (Stanford, 2020).

${ }^{16}$ Emőke Bodonyi, Jeges (Szentendre, 2008).
} 
achieved sudden success with a poster commissioned by the National Propaganda Committee in support of the campaign for Hungary's territorial integrity, then promoted by the liberal government of Mihály Károlyi (1875-1955). The image of Greater Hungary cut up into pieces and the forceful slogan "Nem! Nem! Soha!" ("No! No! Never!") looked ahead to a great career in interwar Hungary. It was probably this commission that drew the attention of the publishers of Bleeding Hungary to Jeges. ${ }^{17}$ Having already gained considerable skill in copper etching, the artist found the perfect technique to support the overall message of the volume. Made up of tiny fine lines, the images looked old-fashioned compared to the woodcuts and linocuts favored by the avant-garde. This effect, enhanced by the archaized lettering used in the place names, underscored the idea that Hungary's claim to the depicted locations was based on historical fact. On the flipside, however, it also cast their Hungarianness as a thing of the past.

In depicting Gothic churches and crumbling castles, Jeges's illustrations emphasized how long the Hungarian Kingdom had existed in the territories in question, but most of the images also carried specific historical references. Saint Elisabeth's Cathedral in Kassa/Košice/Kaschau was not only one of the best preserved and most magnificent Gothic buildings in old Hungary but also the final resting place of Francis II Rákóczi, prince of Transylvania and leader of an uprising against Habsburg rule between 1703 and 1711. He had been reinterred there in 1906, in a ceremony that had been one of the largest displays of Hungarian nationalism in the prewar years. ${ }^{18}$ The illustration showing the town of Eperjes/ Prešov/Preschau depicted a house belonging to the Rákóczi family, where Francis had been held captive by imperial forces in 1703. In the same vein, many of the pictures showed places well known to Hungarians from history books: Segesvár/Sighişoara, where one of the last battles of the 1848-49 Revolution had taken place, claiming the life of the poet Sándor Petöfi; Arad, where thirteen generals of the revolution had been executed on 6 October 1849. One often needed to be aware of these historical references to understand the connections between the images and the texts. The picture of Eperjes, for instance, illustrated a short story in which the ghosts of Rákóczi’s loyal soldiers haunt a dilapidated tavern in the countryside-Eperjes was not mentioned. ${ }^{19}$

The picture of Löcse/Levoča/Leutschau, a town known for exquisite examples of Gothic architecture and art, was followed by an essay arguing that the old territory of Greater Hungary was the natural space for Hungarian artistic production. ${ }^{20}$ It was authored by the art historian Károly Lyka (1869-1965), an associate of the Nagybánya/Baia Mare artists' colony and another figure whose other writings and activities show him to be a moderate liberal rather than a fervent nationalist. His essay stated that Hungarian art was integral to Western art history and that the border between Western art and Byzantine culture corresponded with Hungary's historical borders in the south and the east. Furthermore, it claimed that Hungarian artists had always quickly absorbed new styles from the West but creatively adapted them to their own, genuine, unmistakably Hungarian spirit. Despite Hungary's multiethnicity, many of the greatest artists had been Magyar-born, and those who were not-such as one of the greatest, Mihály Munkácsy (originally Lieb) - had assimilated to Hungarian culture and absorbed its unique features, making them their own. Hence, Hungarian art was distinct from everything else, and by imposing new borders the peace treaty was artificially limiting its organic growth.

The assumption that Hungarian culture was a monolithic, definable entity originated from the nineteenth century, and so did the desire to perfectly grasp its geographical spread. Visual and verbal descriptions of places and their histories-often produced in the context of the emerging tourism industry-played a crucial role in disseminating these ideas, and hence the nationalist project. ${ }^{21}$

\footnotetext{
${ }^{17}$ The illustrations of Bleeding Hungary, and hence the circumstances of the commisson are not discussed in studies of the artist's work.

${ }^{18}$ On the events in Kassa and their wider context see Frank Henschel, "Das Fluidum der Stadt...": Urbane Lebenswelten in Kassa/Košice/Kaschau zwischen Sprachenvielfalt und Magyarisierung 1867-1918 (Göttingen, 2017), 264-80.

${ }^{19}$ Komáromi János, "Sötét van," in Vérző Magyarország: Magyar írók Magyarország területéért, ed. Dezső Kosztolányi (Budapest, 1921), 98-105.

${ }^{20}$ Károly Lyka, "Magyar művészet - magyar határok," in Vérző Magyarország, 87-92.

${ }^{21}$ For a pertinent example see Pieter Judson, "Marking National Space on the Habsburg Austrian Borderlands, 1880-1918," in Shatterzone of Empires: Coexistence and Violence in the German, Habsburg, Russian, and Ottoman Borderlands, ed. Omer Bartov and Eric D. Weitz (Bloomington, 2013), 122-35.
} 


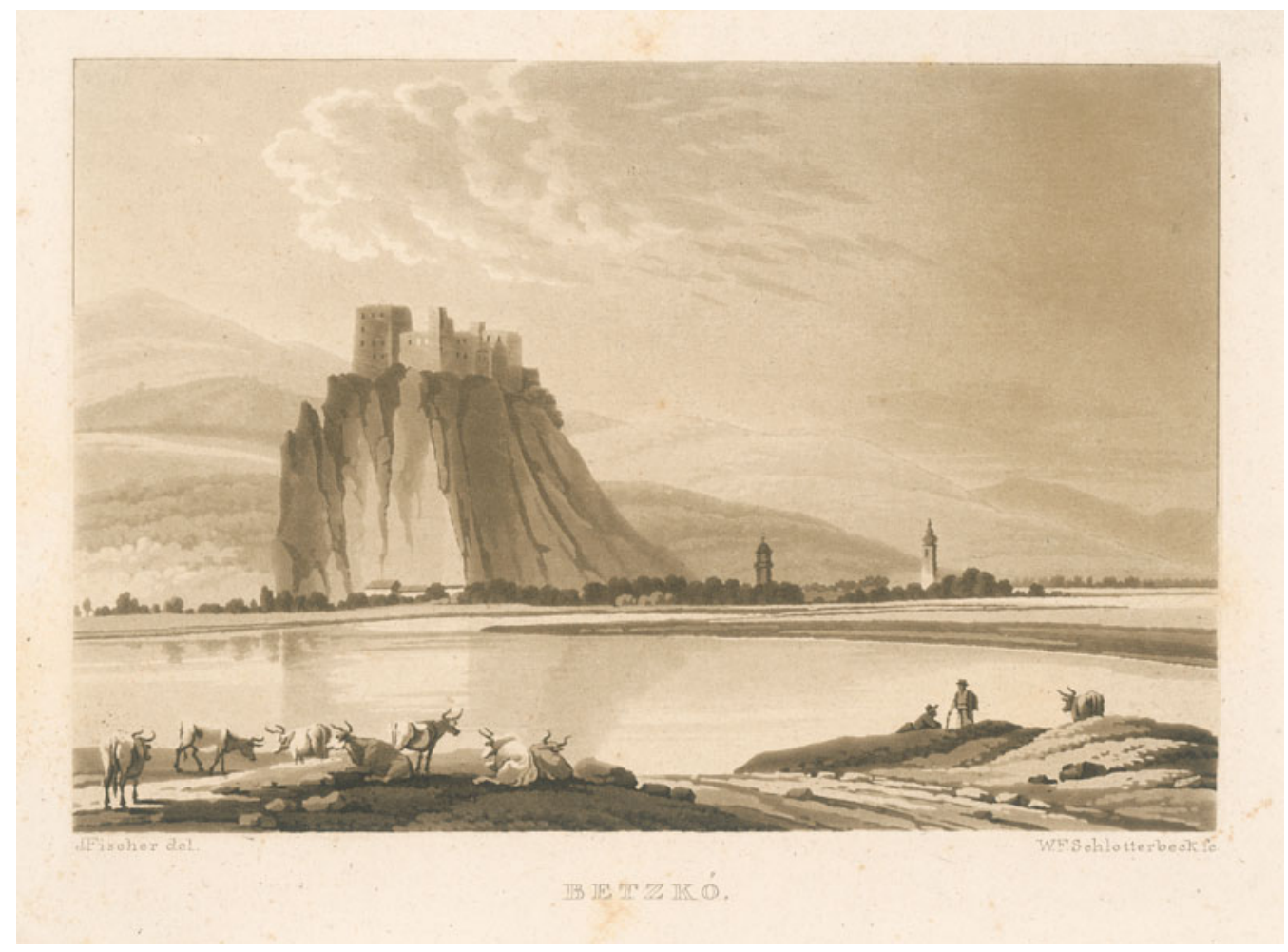

Figure 3: Joseph Fischer, The Castle of Beckó/Beckov/Betzko, 1818, aquatint by Wilhelm Schlotterbeck, Oravská galéria, Dolny Kubín, Inv.No: T 471. Photo: webumenia.sk, public domain.

This ideological work continued in the interwar period, now suffused with post-Versailles grievances. ${ }^{22}$ It would be, however, a major simplification to identify such imagery solely with nationalism. Nineteenth-century landscape imagery contributed just as much to the construction of local and regional identities; indeed, it can be read as an expression of the complex overlap between these and national/imperial identities. ${ }^{23}$ Such complexities did not cease to exist after 1918, but they were suppressed in revisionist arguments, which only highlighted the individual character of regions if it supported the idea of a unified greater whole.

An excellent example of how revisionism overrode the nineteenth century's old mental maps is provided by Bleeding Hungary in its treatment of the region along the river Vág/Váh/Waag (formerly in Northern Hungary, then in Czechoslovakia). For nineteenth-century Hungarians this was a fascinating region full of beauty, legend, and history. It all began with a series of Waag landscapes by the Austrian artist Joseph Fischer (1769-1822), who published them as prints in 1818 (Figure 3). Fischer was one of many artists specializing in the pictorial idiom known as the picturesque. Aiming for a middle ground between the pleasant beautiful and the powerful, terrifying sublime, picturesque landscapes combined beautiful and sublime motifs into compositions that did not inspire fear or terror but still reminded the viewer of the possibility. Picturesque images often accompanied written travelogues, while at other

\footnotetext{
${ }^{22}$ See e.g., Pieter Judson, "Reisebeschreibungen in der 'Südmark' und die Idee der deutschen Diaspora nach 1918," in Zwischen Exotik und Vertrautem: Zum Tourismus in der Habsburgermonarchie und ihren Nachfolgestaaten, ed. Peter Stachel and Martina Thomsen (Bielefeld, 2014), 59-76; Wolfgang Kemp, Wir haben ja alle Deutschland nicht gekannt: Das Deutschlandbild der Deutschen in der Zeit der Weimarer Republik (Heidelberg, 2016).

${ }^{23}$ As Werner Telesko has shown through Austrian examples: “Österreich' und 'seine' Regionen - zur Frage der Mehrfachidentitäten in den Medien der bildenden Kunst im 19. Jahrhundert,” in Jenseits vom Grenzen: Transnationales, translokales Gedächtnis, ed. Moritz Csáky and Elisabeth Großegger (Vienna, 2007), 167-81.
} 
times they formed visual travel accounts of their own. As such, their main aim was to be varied and interesting.

Fischer's pictures turned the Waag region into a desirable travel destination by adapting it to these pictorial conventions. They showed sublime mountains and ruined castles with cows grazing peacefully on the other side of the river, towns with church spires settled in the shadow of the mountains, fishermen steering their boat between menacing cliffs. They often employed characteristically picturesque contrasts between the awe-inspiring landscape in the background and contemporary people, travelers or local peasants, peacefully going about their lives in the foreground.

In 1826, the German-speaking Hungarian writer Baron Alajos Mednyánszky (1784-1844) republished Fischer's images accompanied by a travelogue, which he-a native of the Waag region-had compiled from his previous historical essays about the ruined castles by the river. ${ }^{24}$ Some castles had featured in the grand events of history, but most had not, and Mednyánszky's essays combined historical facts and ethnographic tidbits with ghostly, intriguing legends from local lore to keep his readers hooked. These stories provided writers with material throughout the century, while Fischer's picturesque images of castles and mountains inspired painters of romantic landscapes. They imprinted a unique image of the region into nineteenth-century Hungarian cultural memory.

Given its exceptional status in mental maps, the Vág region could stand in for the whole when it came to visualizing the spatiality of Hungarian culture. When the landscapist Antal Ligeti (1823-90) was commissioned to paint four pictures of Hungarian castles for the lecture hall of the newly built Hungarian Academy of Sciences in 1867-70, the artist and his patrons neither opted for locations in which great historical events had taken place, nor did they choose four locations from the four directions of the compass so as to fully cover the territory of the country. ${ }^{25}$ Instead, they chose two castles from the Vág region, those of Trencsén/Trenčín/Trentschin and Hricsó/Hričov; a third castle, described by Mednyánszky, from Szepes/Spiš/Zips in the north; and a fourth one from Szigliget near Lake Balaton. The cultural significance of these places overrode the need for geographical totality. ${ }^{26}$

With the emergence of photography, the constant improvement of printing methods, and the birth of mass tourism, images of places multiplied in turn-of-the-century visual culture. As Werner Telesko has argued, these pictures not only reiterated but also expanded the early nineteenth century's canon of views worthy of representation. ${ }^{27}$ In this regard, it is instructive to look at The Austro-Hungarian Monarchy in Word and Image (or the Kronprinzenwerk), a monumental book series presenting the empire by regions that was initiated by Crown Prince Rudolph and published between 1885 and 1902 in German and Hungarian editions. Northern Hungary, and with it the Vág region, formed part of volume 18 published in 1899 . The book series was based on the premise that by following a strict geographical order all regions could be covered equally; furthermore, its aim was to provide a succinct overview of historical, demographic, economic, and ethnographic data rather than to dwell on myths and legends or the sublimity of the landscape. The Vág region was presented in the same way as Hungary's other regions. Some of the illustrations showed the same picturesque views as Fischer's images, while others added new imagery, such as close-ups of buildings in towns or depictions of local industrial products (Figure 4). Given that its priorities were different, the text did not follow the canon of places created by Fischer and Mednyánszky: some of the locations mythicized by the latter two were only fleetingly mentioned, while others, not prominent in legends but important

\footnotetext{
${ }^{24}$ Aloys Freyherr von Mednyánsky, Malerische Reise auf dem Waagflusse in Ungern (Pest, 1826). The tales were also retold in Mednyánszky's subsequent publication: Erzählungen, Sagen und Legenden aus Ungarns Vorzeit (Pest, 1829), as well as in its next editions.

${ }^{25}$ On the commission see Júlia Szabó, in A Magyar Tudományos Akadémia képzőmüvészeti kincsei, ed. Gábor Papp György and Edit András (Veszprém, 2004), 225-28, Cat. No 109 a-d; R. O. [Orsolya Radványi], "Magyarország történelmi várai és tájai, 1850-1880-as évek," in Ligeti Antal (1823-1890): A természettanulmánytól a mestermüig, ed. Katalin Blaskóné Majkó et al. (Budapest, 2008), 85.

${ }^{26}$ For more on Mednyánszky and his influence in the visual arts see Nóra Veszprémi, "Kísértetek a végtelen rónán. A magyar romantika rettenetes hagyományáról,” in XIX. Nemzet és müvészet. Kép és önkép, ed. Erzsébet Király, Enikő Róka, and Nóra Veszprémi (Budapest, 2010), 139-66.

${ }^{27}$ Werner Telesko, "Visualisierungsstrategien im Tourismus in der Spätphäse der Habsburgmonarchie: Postkarten, Plakate und andere Bildmedien," in Zwischen Exotik und Vertrautem, 31-46.
} 


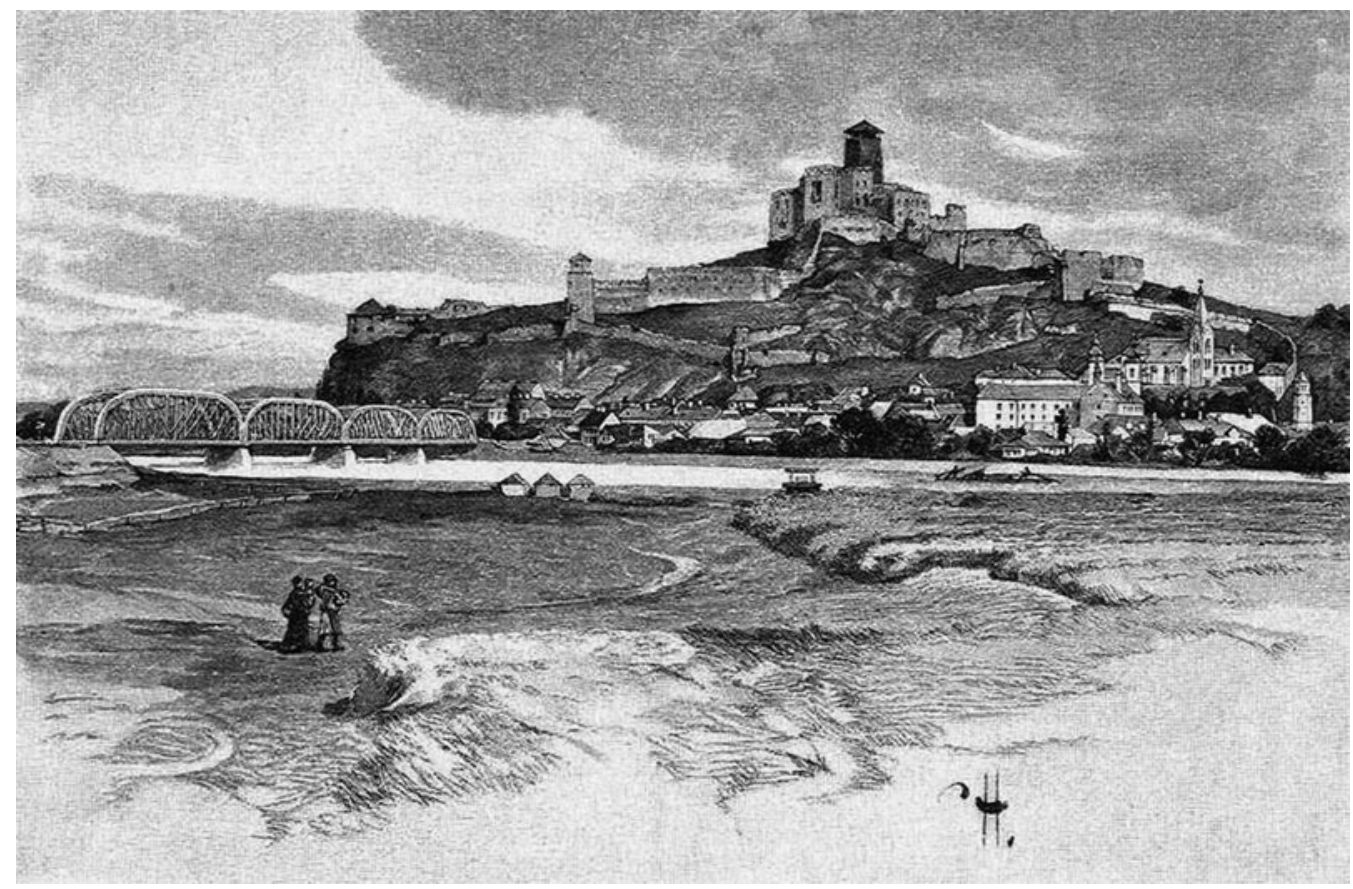

Figure 4: Gyula Háry, The town of Trencsén/Trenčín/Trentschin and the castle, illustration from Az Osztrák-Magyar Monarchia írásban és képben, vol. 18, Hungary, vol. 5 (Budapest, 1899), 325. Photo: public domain.

to industry, were discussed in more detail. Hence, the romantic character of the Vág region was diluted in the Kronprinzenwerk. But it was not lost. At certain points, the sober, factual text slipped into poetic descriptions of the never completely harnessed landscape. ${ }^{28}$ The images not only included several ominous ruined castles but also close-ups of savage rocks and narrow mountain passages, much in the manner of Fischer's most disconcerting illustrations.

In this way, the Kronprinzenwerk created a new, expanded canon of imagery related to the Vág region, preserving its character but honing it to fit neatly into a complete picture of the empire. Less than twenty years after the last volume was published, the empire was shattered. Publications such as Bleeding Hungary grappled with a double bind: they needed to aim for completeness, like the Kronprinzenwerk, to promote the territorial integrity of Greater Hungary, but they also had to emphasize the brokenness-indeed, their entire existence was predicated on the fact that the rupture had happened. This was reflected in how Bleeding Hungary recontextualized the Vág region's memory sites.

The book contained two pictures of castles near the Váh: Árva/Orava/Arwa (Figure 5) and Beckó/ Beckov/Betzko (Figure 1). Árva was connected to a relatively well-known historical event: its owner, the powerful Hungarian nobleman István Thököly had taken part in an anti-Habsburg conspiracy in 1670. The castle was besieged by the Austrian army, and the older Thököly died in the siege. His young son, Imre Thököly, however, escaped and subsequently led of a series of uprisings. Beckó, by contrast, had no such claim to fame: it owed its popularity solely to an appearance in one Mednyánszky's tales. As legend had it, the castle had been inhabited by the ruthless Voivode Stíbor, who once had an old peasant thrown from the cliff because, when attacked by one of the voivode's dogs, he had broken the animal's leg while trying to escape. A year later the voivode died a similarly horrible death: blinded by a snakebite while dozing off in the garden, he stumbled off the cliff and fell to his death. The legend was retold many times in the nineteenth century, one of the first such

\footnotetext{
${ }^{28}$ Gyula Lovcsányi, “Trencsénmegye," in Az Osztrák-Magyar Monarchia írásban és képben, vol. 18, Hungary, vol. 5 (Budapest, 1899), 294-331.
} 


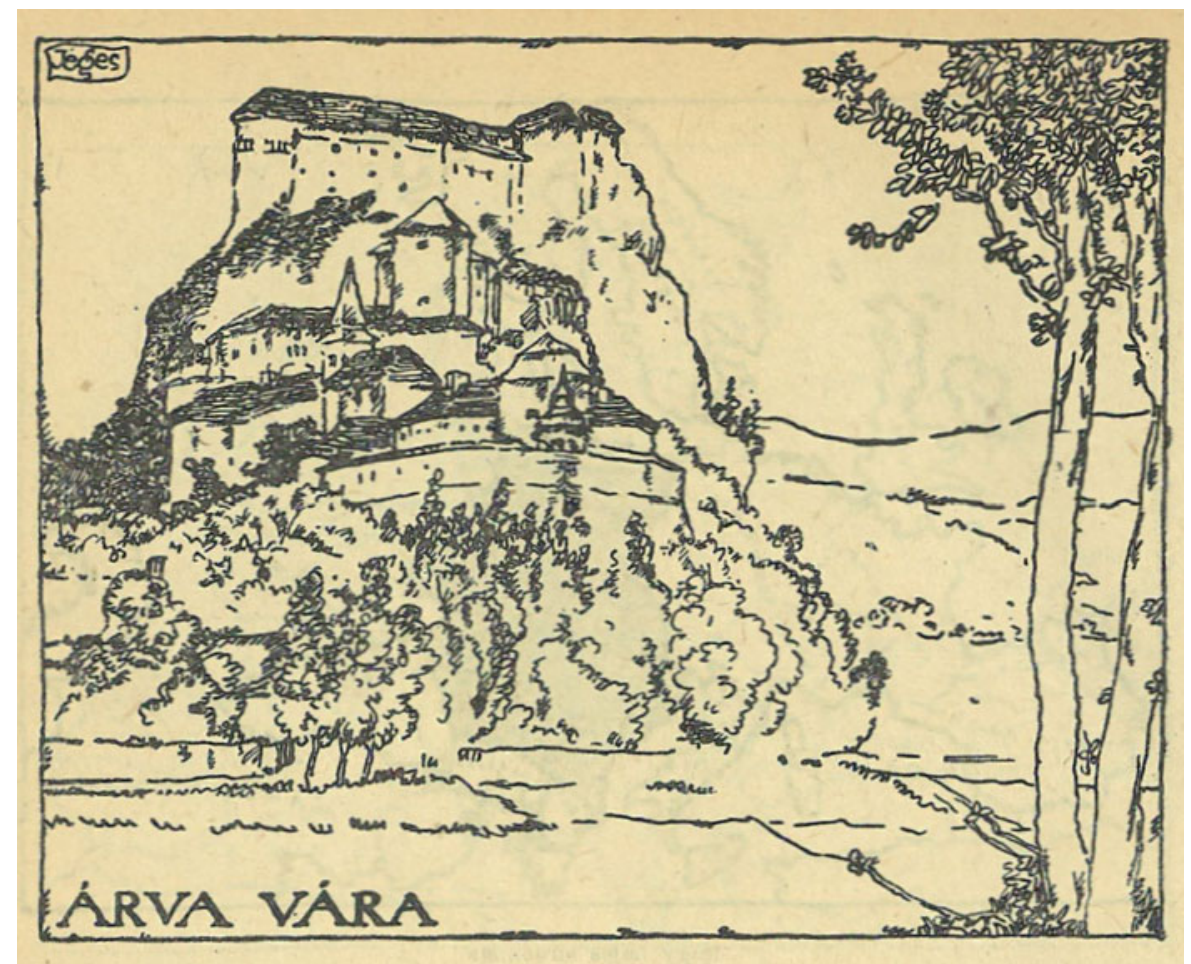

Figure 5: Ernő Jeges, The Castle of Árva/Orava, illustration from Vérző Magyarország: Magyar írók Magyarország területéért, 202. Photo: public domain.

instances being an 1820 play by Károly Kisfaludy (1788-1830). It was multiethnic like the Vág region: Stíbor had been of Polish descent, while the peasants living in the area were partly Hungarian, though mainly Slovak speakers, and the tale probably originated from Slovak lore. All this, however, went unmentioned in Bleeding Hungary. Together with the rest of the locations, Beckó became a patriotic reminder of old Hungarian history, and its tale lost both its multiethnicity and its gothic edge.

This transformation is also apparent in Jeges's images, the majority of which provided sober depictions of landmarks such as individual buildings or town squares, without complementing them with dramatic landscapes as in the Kronprinzenwerk. In the case of Beckó and Árva, the artist had a rich picturesque tradition to draw on, but he only did so fleetingly. Paying some respect to the principle of variety, the image of Beckó complements the ancient ruins with peasant's houses in the foreground, and the picture of Árva dutifully employs the traditional compositional device of placing a tree in the foreground, to the side, while the castle looms in the background. But there are no striking contrasts, no swirling clouds, no emphasis on the sublime, and no figures navigating the landscape or enjoying the picturesque view. It seems that, in being more prosaic, Jeges sought to emphasize the documentative nature of his images to provide the volume with an authoritative, nonsubjective air. The individual character of the Vág region, its rich web of cultural associations, was subordinated to this goal in a more definitive manner than in the Kronprinzenwerk. The latter publication aimed at totality but presented it as a sum of diverse parts. Bleeding Hungary, however, had one specific political message, and the map it presented was shaped by that message alone.

This, in the end, meant that Bleeding Hungary's map was incomplete. The illustrations only showed places from the lost territories, and it was only in these areas that the appendix highlighted the birthplaces of famous Hungarians. The remaining area of Hungary-which opponents of Trianon referred to as "Dismembered Hungary" (Csonka-Magyarország) - was left empty. Bleeding Hungary was an early example of an attitude that has since had a decisive effect on Hungarian mental maps, one that treats the former Hungarian lands outside the new borders as an integral whole that is 
conceptually separate from the land that remained. Perhaps inevitably, the "lost territories" came to be romanticized in historical memory as one single site of memory, leading to an ever-growing distance between actual Slovakian, Romanian, or Ukrainian Hungarian ways of life and their representations within the borders of Hungary. ${ }^{29}$

\section{Filling the Gap: Maps of Consolidation}

The years immediately following World War I were years of extreme political turbulence in Hungary, replete with shock, controversy, and violence. The country struggled to fight the Czechoslovak, Romanian, and Serbian troops that seized territories before the border changes were made official. The democratic Aster Revolution of October 1918 was followed by a Communist Council Republic established on 21 March 1919, which was in turn overthrown by Horthy's counterrevolution and the White Terror of paramilitary troops. In 1920 the Hungarian parliament voted for the first anti-Jewish law in twentieth-century Europe: the numerus clausus law did not explicitly mention Jews, but its limitations on the numbers of university students belonging to minority groups were obviously aimed at them. Hostilities within society, ramped up by the news of Trianon, were extreme.

In April 1921, István Bethlen (1874-1946), an emblematic opponent of the short-lived Liberal Károlyi and, subsequently, Communist governments, became prime minister. Realizing that tensions needed to be deescalated to keep the country running, Bethlen aimed for a politics of consolidation. ${ }^{30}$ He signed an agreement with the Social Democrats and sought to disempower (with only temporary success) the extreme right both within and outside his party, while upholding the right-wing autocracy that was the Horthy regime. In 1928 his government withdrew the most clearly discriminatory passages of the numerus clausus law. His foreign policy was led by the conviction that Hungary's borders should be modified, but preferably through legal rather than military means. Together with his minister of religion and education, Kunó Klebelsberg (1875-1932), he promoted the idea of the superiority of Hungarian culture in the Carpathian Basin-adding, however, that the badge of superiority had to be earned. Hence, while waiting for the revision of Trianon, Hungarians in new Hungary needed to concentrate their efforts on nurturing Hungarian culture and education in the remaining land.

A comparison between Bleeding Hungary and a revisionist album published between 1928 and 1930 in five different language editions reflects the difference between the two approaches. Produced by the Budapest publishing house Légrády Brothers, Justice for Hungary! aimed to persuade audiences at home and abroad of the "cruel errors of Trianon." 31 In addition to essays highlighting the injustices suffered by the Hungarian nation, the book also contained a rich selection of images, providing an overview of Hungarian history and cultural heritage within and outside the new borders. Like Bleeding Hungary, it aimed to demonstrate the organic unity of the land through these cultural artefacts but, unlike the earlier publication, it also included locations in "Dismembered Hungary" within its purview.

The very first image in the album-seen both on the front cover and the frontispiece-was a depiction of the map of Greater Hungary nailed to a cross (Figure 6). The image became hugely popular and was subsequently disseminated through postcards and other publications by revisionist organizations. According to Katalin Sinkó, this image replaced "the imperial concept of the nation, which accepted multiple ethnicities (the concept originally evoked by the image of the map) [with] a national consciousness based on just a single ethnicity." ${ }^{32}$ As I will demonstrate in the following text, this drive for homogenization can be discerned throughout the album.

\footnotetext{
${ }^{29}$ On this discrepancy in the interwar period see László Szarka, "Hungarian National Minority Organizations and the Role of Elites between the Two World Wars: Addenda to the History of Minority Nationalism in Central and Eastern Europe," The Hungarian Historical Review 2, no. 3 (2013): 413-48.

${ }^{30}$ Ignác Romsics, Bethlen István: Politikai életrajz (Budapest, 2019). A shorter, English version: Ignác Romsics, István Bethlen: A Great Conservative Statesman of Hungary, 1874-1946 (Boulder, 1995).

${ }^{31}$ This article refers to the English version: Ottó Légrády, ed., Justice for Hungary! The Cruel Errors of Trianon (Budapest, 1930). The volume was also published in Hungarian, German, French, and Italian. See Nóra Veszprémi, "Place, Memory, Propaganda: The 1930 Album Justice for Hungary!," accessed 20 June 2020, https://craace.com/2019/07/19/place-memorypropaganda-the-1930-album-justice-for-hungary/.

${ }^{32}$ Sinkó, "The Offended Hungária," 21-22.
} 
Figure 6: Hungary Crucified, frontispiece illustration from Ottó Légrády, ed., Justice for Hungary! The Cruel Errors of Trianon (Budapest, 1930). Photo: public domain.

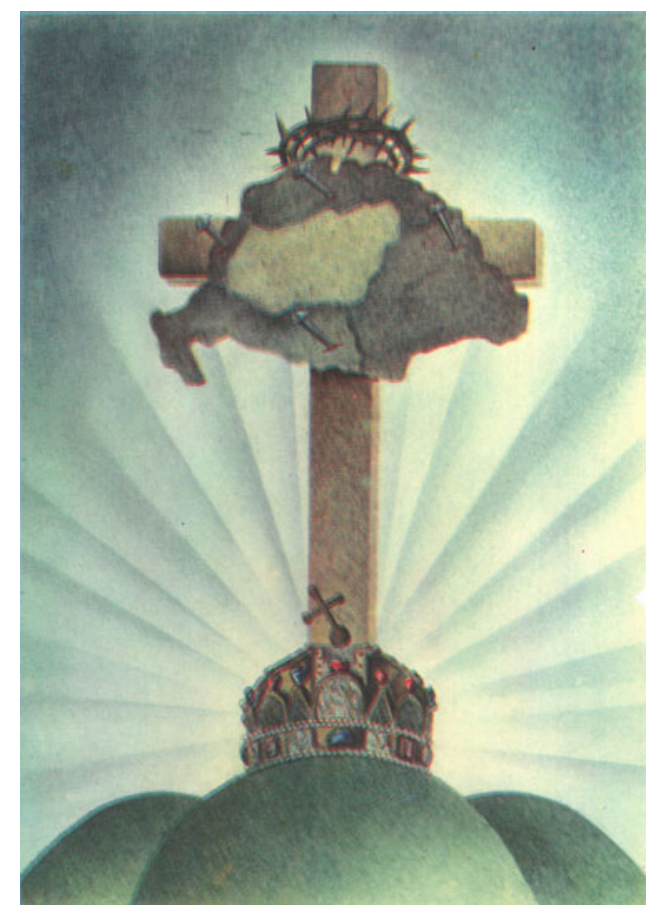

The image section of Justice for Hungary! was introduced by a short text on The Thousand Years' [sic] Struggles of the Hungarian Nation followed by a selection of pictures from the nation's history; then, a discussion of The Hungarian Genius was illustrated by images of Hungarians' greatest cultural achievements. ${ }^{33}$ The section, as a whole, can be characterized as a visual essay. It began with photos of monuments erected as part of the Millennium Celebrations in 1896-monuments subsequently destroyed, as the book put it, by the "fury," "spite," and "hatred" of the Czechs, Romanians, and Yugoslavs. ${ }^{34}$ Subsequent images presented important historical figures and events, such as King Stephen I, Hungary's first king, King Matthias Corvinus, its Renaissance ruler, or the fifteenth- to seventeenth-century battles against the Turks, in chronological order. In a manner familiar from Bleeding Hungary, the pictures showed places and buildings associated with these personalities or events: some were contemporary photographs, others reproduced nineteenth-century depictions. Further images showed historical events, most of them reproductions of nineteenth-century paintings.

Compared to Bleeding Hungary, Justice for Hungary! struck a more peaceful tone, in line with the politics of consolidation. In its own way, it even argued for a compromise with other nationalities, acknowledging their role in Hungarian history-although this never went so far as to abandon the idea of Hungarian hegemony and cultural superiority. It mentioned, for instance, that the Zrínyisa noble family prominent in the sixteenth and seventeenth centuries-had had dual Hungarian-Croatian identity, or that many of Rákóczi's soldiers had been Slovaks, but the purpose was always to prove the historical necessity of Hungarian hegemony over these groups. ${ }^{35}$ Places like the vibrantly multiethnic Kassa/Košice/Kaschau were described as "pure Hungarian" towns, and the castles that had evoked romantic and exciting tales in the literary tradition started by Mednyánszky were now solely important because of their connections to great events and personalities. ${ }^{36}$ In many

\footnotetext{
33“"The Thousand Years' Struggles of the Hungarian Nation" and "The Hungarian Genius: What It Has Achieved during Ten Centuries of History," in Justice for Hungary! The Cruel Errors of Trianon, ed. Ottó Légrády (Budapest, 1930), 41-108, 109-64.

${ }^{34}$ Légrády, ed., Justice for Hungary!, 45. On the political background of these monuments and their subsequent fate see Bálint Varga, The Monumental Nation: Magyar Nationalism and Symbolic Politics in Fin-de-Siècle Hungary (Oxford, 2016).

${ }^{35}$ Légrády, ed., Justice for Hungary!, 42, 75, 82.

${ }^{36}$ Ibid., 60 .
} 


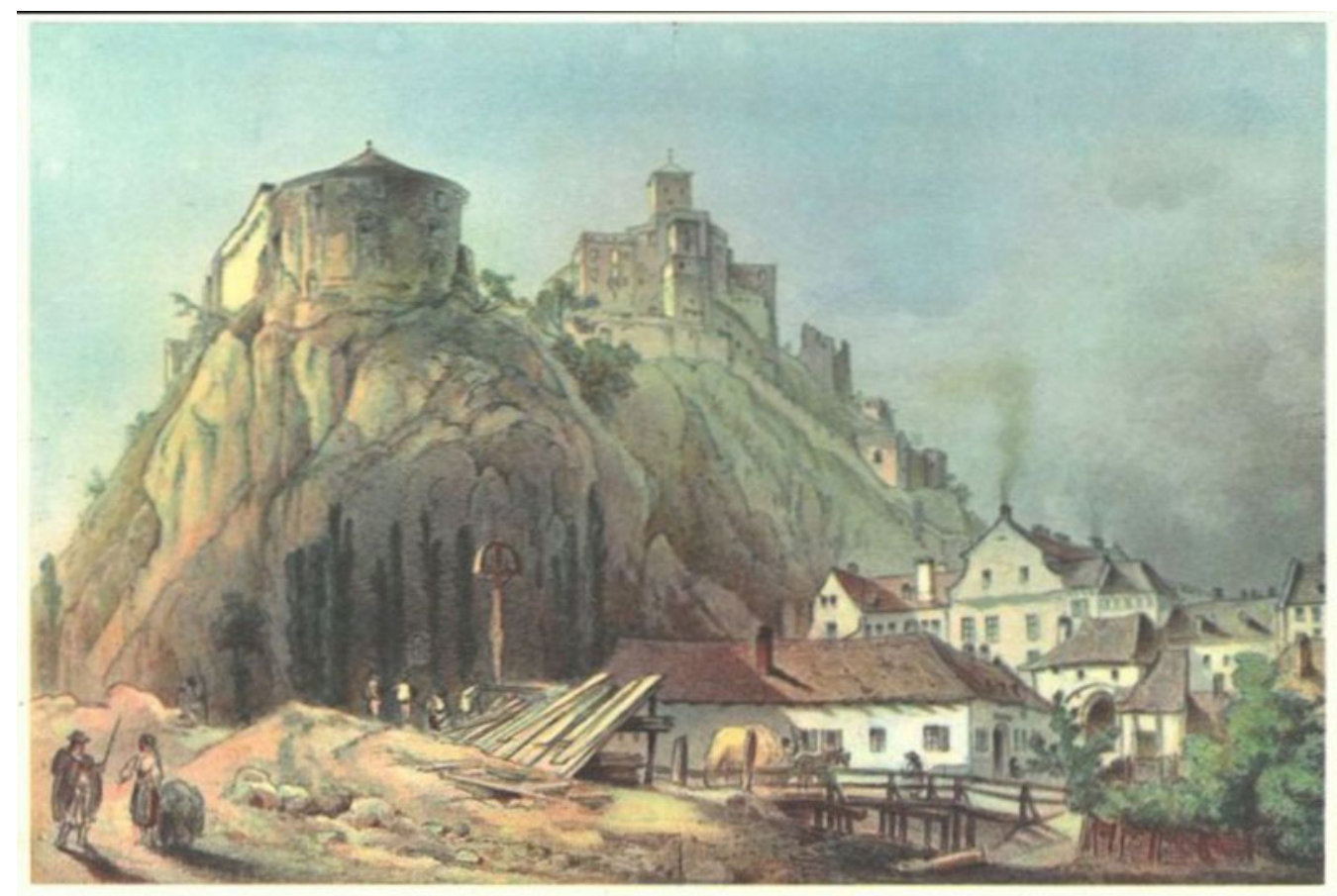

Figure 7: The Castle of Trencsén/Trenčín/Trentschin, nineteenth-century English lithograph, illustration from Justice for Hungary! The Cruel Errors of Trianon, 50. Photo: public domain.

cases, the album recycled nineteenth-century images, but its commentary completely eschewed the suspenseful themes and colorful language of the picturesque. The castle of Trencsén, for example, was represented by a nineteenth-century English lithograph-an image in itself less dramatic than depictions by Fischer or Ligeti-while its significance was explained in the caption solely by the fact that it had been the center of a burgravate established by Stephen I (Figure 7). ${ }^{37}$

Like Bleeding Hungary, Justice for Hungary! downplayed regional characteristics in favor of the idea of a unified Hungary, and it did so perhaps in an even more definitive manner. Avoiding any suggestion of a geographical order-which, like in the Kronprinzenwerk, would have suggested a unification of diverse parts-the locations were depicted chronologically, in the order in which they had played a role in Hungary's history. This grand narrative was made up of the stories of individual events and the lives of great men, which zigzagged across the imagined map of Hungary. To return to a previous example, Francis II Rákóczi was represented by a photo of the Rákóczi House in Eperjes, an eighteenth-century engraving showing a member of his " $k u r u c$ " army, his portrait painted by Ádám Mányoki (1673-1757), a 1617 townscape of Kassa and a colored print showing its cathedral, as well as paintings of scenes from Rákóczi's life taking place in Nagysáros/Velký Šariš (which, in 1930, was in Czechoslovakia) and Ónod (in northeastern Hungary). The life of Rákóczi-a prince of Transylvania-connected "Dismembered Hungary" with territories that now lie in Romania and Czechoslovakia, presenting Greater Hungary as an inseparable whole.

Unlike in Bleeding Hungary, in this later publication "Dismembered Hungary" was not an empty space. In a certain sense, the book's real focus was on this area and not on the territories it reclaimed. According to the politics of consolidation, the new, smaller Hungary was to become a cultural hub that could stand in for the lost territories, hopefully not for a long time, but-and this was always implicitpossibly for an indefinitely longer term. The visual essay provided a perfect encapsulation of this idea. A double page, for instance, juxtaposed the medieval Castle of Vajdahunyad/Hunedoara, ancestral

\footnotetext{
${ }^{37}$ Ibid., 50.
} 

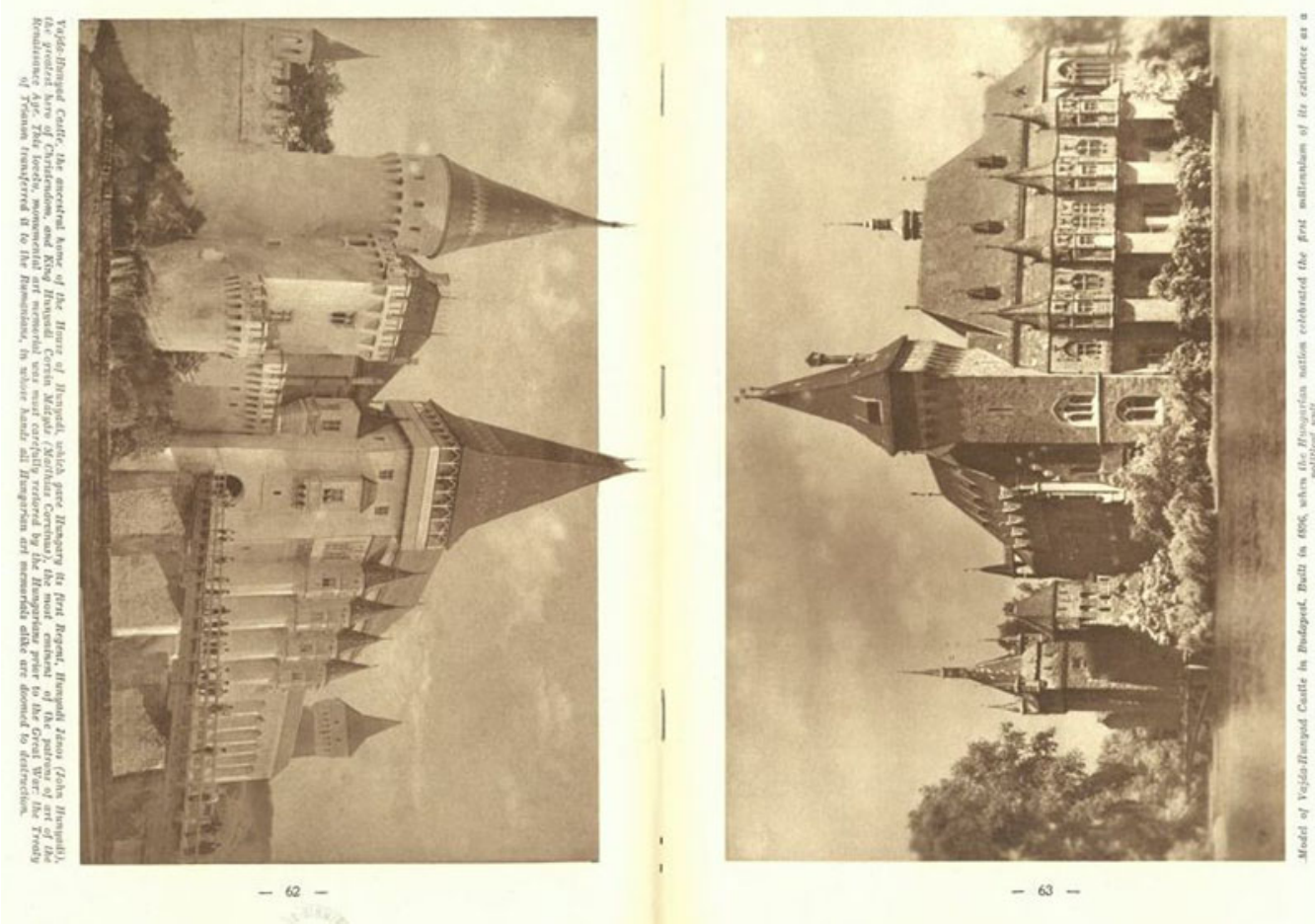

Figure 8: The Castle of Vajdahunyad/Hunedoara and Vajdahunyad Castle, illustrations from Justice for Hungary! The Cruel Errors of Trianon, 62-63. Photo: public domain.

home of Matthias Corvinus, with the historicist Vajdahunyad Castle, built in the Budapest City Park in 1896 as part of the Millennium Celebrations (Figure 8). ${ }^{38}$ Whatever they thought of historicist architecture, few people at the time would have doubted that the medieval castle was the venerable historical landmark, while the version in Budapest was at best an imitation. Nevertheless, by presenting the two in photos of equal size on a double page, the album implied that there was no difference in value. On one level, the pairing of the images provided further proof of the indivisible cultural ties within Greater Hungary, but on another it suggested that landmarks still accessible in small Hungary could offer solace to those mourning the loss of important memory sites. Hence, the volume transmitted a certain resigned message despite its revisionist rhetoric: that while we lament what we have lost and attempt to reclaim it, we also need to enumerate and appreciate what we have left because, in the end, this is what we have as a replacement.

In this vein, Justice for Hungary! contained several examples in which places in "Dismembered Hungary" stood in for places in the lost territories. The old University of Kolozsvár had moved to Szeged, a "lovely town in the Hungarian Lowlands," while retaining its name: the "Francis Joseph University of Sciences of Kolozsvár." Another image showed the "lovely resort" of Lillafüred, which provided "a certain compensation" for all the mountain resorts and spas lost as a result of Trianon. The album extolled the beauties of Budapest and dwelled on Lake Balaton, often referred to as "the Hungarian sea." As the book explained, "This humorous saying has a sadly tragic truth in it; for it has now become fact that we have been deprived of our real sea-board." ${ }^{39}$ In the mental map that emerged from Justice for Hungary!'s images, the historical and cultural memories associated with places in Greater Hungary were collapsed into the smaller Hungary that was left after the rupture.

\footnotetext{
${ }^{38}$ Ibid., 62-63. On the nineteenth-century building see Gábor Rosch et al., Vajdahunyad Castle (Budapest, 2007).

${ }^{39}$ Légrády, ed., Justice for Hungary!, 138.
} 
As is often pointed out in memory studies, memory is a process rather than a fixed entity. ${ }^{40}$ The shaping and mediation of collective memory involves ongoing work, while the canons and interpretations of memory sites are subject to constant revision in line with the political and cultural aims of different groups. ${ }^{41}$ The differences between Bleeding Hungary and Justice for Hungary! show that even the revisionist memory politics of the Horthy regime were not monolithic but rather negotiated constantly, with inner contradictions surfacing even within the same volume. In the next sections of this article, the introduction of Czechoslovak viewpoints will further complicate this picture of interwar collective memory. By focusing on landscapes, it is nevertheless possible to draw together these diverse, intersecting perspectives.

\section{The View from the Other Side of the Border: Czechoslovakia}

The entangled histories of Central European nations produced overlapping mental maps. The same places and same historical events could take on different, even opposing meanings in different national narratives; but nevertheless, they were still the same places and the same historical events. They connected those narratives, even when they embodied conflict. This is why the concept of mental maps is particularly useful in exploring Central European historical memory: by directing our attention onto spatial relationships as both material realities and constructions, it helps us grasp and visualize these connections.

In memory studies there has recently been growing interest in the relationship between memory and spatiality. ${ }^{42}$ An important reference point for such an approach is Pierre Nora's monumental series of edited volumes on "les lieux de mémoire" - sites of memory-in French culture. ${ }^{43}$ The terminology is somewhat misleading; by "sites of memory" Nora was not necessarily referring to geographical places but to historical events or concepts that serve as cornerstones in national narratives of history and take on a symbolic meaning in the nation's understanding of itself. ${ }^{44}$ Nevertheless, while sites of memory are not necessarily spatial, they are often connected to actual geographic locations. In this way, the concept certainly has a geographic dimension, even if its full scope is broader. Although the concept of sites of memory was developed to understand the historical memories of nations, this ambivalence-its simultaneously spatial and immaterial nature-allows it to be employed as a useful tool in transnational investigations. By looking at the overlapping mental maps of different groups, it is possible to transcend the national framework and explore the transcultural aspects of competing historical memories. ${ }^{45}$ It is with this in mind that we now shift our attention from Hungary to interwar Czechoslovakia.

Czechoslovakia was formed in 1918, and its new borders were officially sanctioned in 1920. As an admittedly multinational state, it aimed to forge a Czechoslovak identity encompassing Czechs, Slovaks, as well as the other nationalities of the country. The division here between Czechs and Slovaks, on the one hand, and the "others," on the other hand, is intentional: although Czechoslovakia can rightly be described as the most democratic of Austria-Hungary's successor states, its ethnic politics were nevertheless imbalanced. Czechs and Slovaks were positioned as the two state-

\footnotetext{
${ }^{40}$ Jeffrey Olick, "From Collective Memory to the Sociology of Mnemonic Practices and Products," in A Companion to Cultural Memory Studies, ed. Astrid Erll and Ansgar Nünning (Berlin, 2010), 159.

${ }^{41}$ Ann Rigney, “The Dynamics of Remembrance: Texts between Monumentality and Morphing," in A Companion to Cultural Memory Studies, 345-46; Rigney, "Remembrance as Remaking: Memories of the Nation Revisited," Nations and Nationalism 24, no. 2 (2018): 240-57.

${ }^{42}$ Jonathan Boyarin, ed., Remapping Memory: The Politics of TimeSpace (Minneapolis, 1994); Jeffrey K. Olick and Joyce Robbins, "Social Memory Studies: From 'Collective Memory' to the Historical Sociology of Mnemonic Practices," Annual Review of Sociology 24 (1998): 105-40, 117; Lorraine Ryan, Memory and Spatiality in Post-Millennial Spanish Narrative (New York, 2016).

${ }^{43}$ For the most recent English version of the volumes see Pierre Nora, ed., Rethinking France: Les Lieux de mémoire, vol. 1: The State; vol. 2: Space; vol. 3: Legacies; vol. 4: Histories and Memories (Chicago, 1999, 2006, 2009, and 2010).

${ }^{44}$ On the concept see Pim den Boer, "Loci memoriae-Lieux de mémoire," in A Companion to Cultural Memory Studies, 19-26.

${ }^{45}$ On the recent transcultural turn in memory studies: Jessica Rapson and Lucy Bond, eds., The Transcultural Turn: Interrogating Memory between and beyond Borders (Berlin, 2014); Chiara de Cesari and Ann Rigney, eds., Transnational Memory: Circulation, Articulation, Scales (Berlin, 2014). For examples of transnational/translocal discussions of sites of memory see Csáky and Großegger, eds., Jenseits von Grenzen.
} 
forming nationalities, while Germans, Hungarians, and other minorities faced difficulties in asserting themselves in the political sphere. ${ }^{46}$ There was, too, a certain imbalance between Czechs and Slovaks. One of the tenets of the Czechoslovak identity promoted by the state was modernity, which involved social and industrial progress. These were mainly associated with the highly industrialized Czech lands, while rural Slovakia was conceptualized as a romantic, uncivilized land notable for its beautiful landscape and vernacular crafts. The nostalgic attitude of Czechoslovak artists and commentators toward the region was not dissimilar from the nostalgic attitude of Hungarian revisionists, even though the two originated from two opposing political standpoints. Despite their ideological differences, their cultural references were similarly rooted in the Austro-Hungarian past.

One such cultural reference point was the journey down the Váh, as popularized by Mednyánszky and Fischer. In his series Dolu Váhom (Down the Váh), the Moravian-born artist and printmaker Ferdiš Duša (1888-1958) retraced the journey mapped in Picturesque Journey along the River Waag in Hungary. The prints were made for the Bratislava-based publisher K. Jaroň, who published some of them in 1933 under the title Down the Váh, accompanied by an introduction by the Swiss writer William Ritter (1867-1955). ${ }^{47}$ In 1934 Jaron republished fifteen prints in a more representative album, accompanied not just by Ritter's text but also by descriptions of the individual locations. ${ }^{48}$ This album was intended as volume 1: it only takes us halfway along the river. Volume 2 was never published but prints that would have formed part of it can be found in museum collections in Slovakia and the Czech Republic. The reason for aborting the project is unknown; perhaps sales were not as successful as Jaron would have liked. What is clear, however, is the political intent behind the publication: the promotion of Slovak national identity. The 1934 edition exists with two slightly different frontispieces. According to one, the purpose of the images was to decorate schools, offices, and homes, while the other stressed the use of the images in formal education: Dolu Váhom "originated from a love for Slovakia and Slovak schools," and its purpose was to provide the latter with an "artistic educational aid" in teaching the geography and history of the homeland. ${ }^{49}$

In the early nineteenth century, Mednyánszky's aim had been to demonstrate that the ethnically diverse Vág region belongs to the Habsburg Empire, and within it to Hungary. ${ }^{50}$ Duša, by contrast, conceptualized the Váh as a Slovak river and completely avoided other ethnicities. This was made explicit in the accompanying text by Ritter, which bears the title Roman slovenskej rieky (Novel of a Slovak river). ${ }^{51}$ Ritter, a Slavophile who spent much time in Prague and Slovakia, championed the idea that identity was a product of rootedness in a certain place. ${ }^{52}$ His cultural conservatism made him oppose not only liberal internationalism but also the efforts of the Czechoslovak state to construct a new Czechoslovak national identity built on ideas of modernity. In this, as well as in his devout Catholicism, his ideas corresponded with the increasingly radical Slovak nationalist movement. ${ }^{53} \mathrm{He}$ called the Váh the Slovak national river because it flows exclusively through Slovak land, and described it as "fidgety and swift then dreamy and calm ... born in the most

\footnotetext{
${ }^{46}$ On ethnic tensions in Czechoslovak politics see Mary Heimann, Czechoslovakia: The State that Failed (New Haven, 2009), 64-75.

${ }^{47}$ Ferdiš Duša, Dolu Váhom/William Ritter, Roman slovenskej rieky (Bratislava, 1933).

${ }^{48}$ Ferdiš Duša, Dolu Váhom I. diel, introduction by Rudolf Kratochvíl (Bratislava, 1934).

${ }^{49}$ Ibid., s. p.

${ }^{50}$ On Mednyánszky’s “imperial patriotism” see Edit Szentesi, "Birodalmi patriotizmus: Történelemszemlélet, történetírás, történeti publicisztika és történeti témák ábrázolása az Osztrák Császárságban 1828-ig,” in Történelem-kép: Szemelvények múlt és müvészet kapcsolatából Magyarországon, ed. Árpád Mikó and Katalin Sinkó (Budapest, 2000), 73-91, summary in German: 779-81.

${ }^{51}$ Duša, Dolu Váhom/Ritter, Roman slovenskej rieky, 5-9.

${ }^{52}$ On Ritter see Philippe Kaenel, "William Ritter (1867-1955): un critique cosmopolite, böcklinien et anti-hodlérien," Schweizerische Zeitschrift für Geschichte 48, no. 1 (1998): 73-98; Lenka Bydzovská, “Heart in a Trance’: William Ritter and Czech Modernism," accessed 6 June 2020, http://www.circe.paris-sorbonne.fr/IMG/pdf/lenka_bydzovska_william_ritter_ 22_2_2011_fini.pdf; Marta Filipová, Modernity, History and Politics in Czech Art (New York, 2019), 38, 76.

${ }^{53}$ See Thomas Lorman, The Making of the Slovak People's Party: Religion, Nationalism and the Culture War in Early 20th-Century Europe (London, 2019), 149-218.
} 


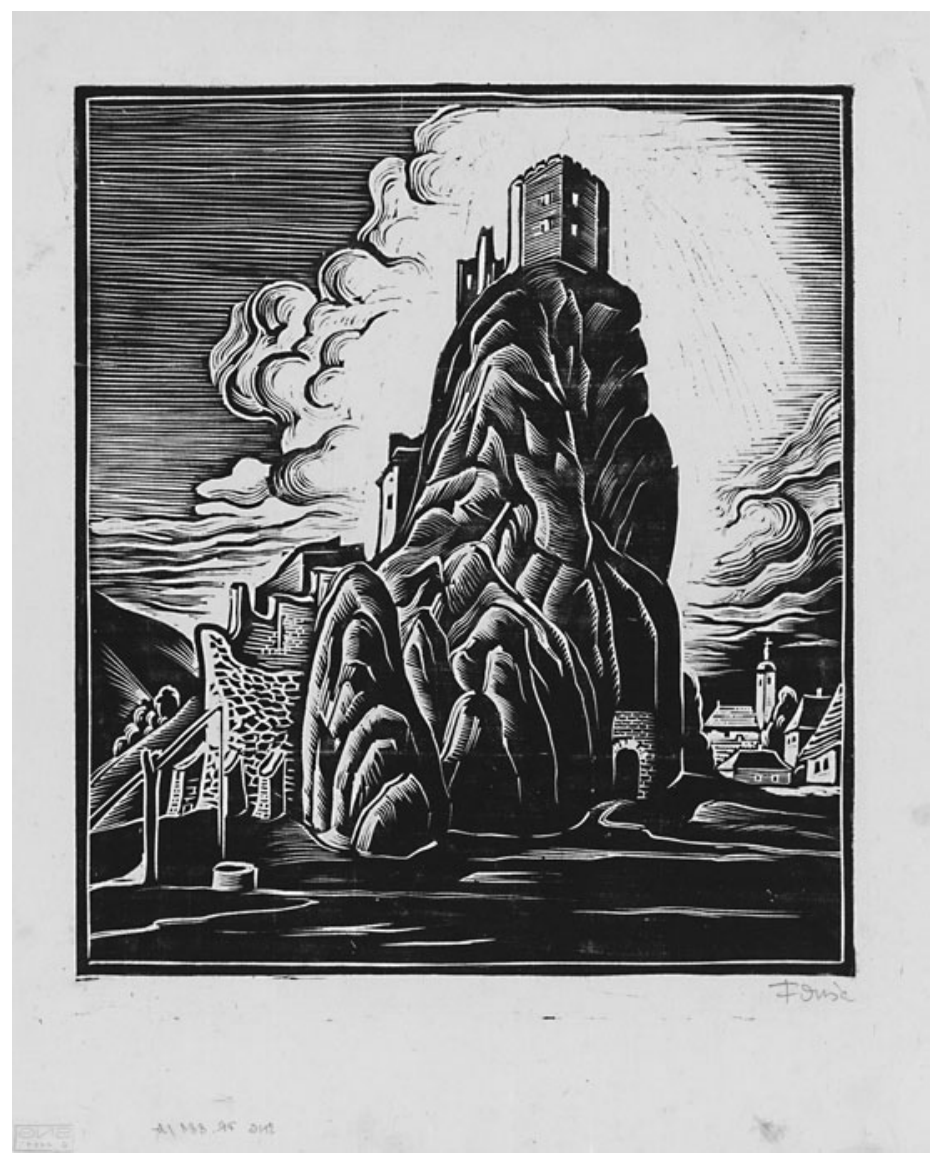

Figure 9: Ferdiš Duša, Beckov/Beckó/ Betzko, 1932-33, from the series Dolu Váhom, Slovak National Gallery, Bratislava, Inv. No: G 1129. Photo (c) Slovenská národná galéria.

romantic place in the land, its extraordinary water reflects ruins along its banks, and flows through the most beautiful region."

In line with this agenda, all the human figures that appear in Duša's images are Slovaks, identified by their traditional garments. They are all peasants and appear to be living a rural idyll while tending to their crops or animals. The exoticization of Slovakia as rural and primitive was part of the official Czechoslovak narrative, but-as exemplified by Down the Váh-it also formed an important part in constructions of a separate Slovak national identity. Slovakia, as depicted in these prints, could be characterized by three main elements: its dramatic, mountainous, yet fertile landscape; its undefined ancientness, embodied by the ruined castles; and its people, whose lives, minds, and identities are inseparable from the land they inhabit. In many of the prints, ruined castles can be seen in the background, while the Slovak peasants going about their day in the foreground seem to receive more emphasis, as if to say that the past-the historical past when the region had belonged to Hungary and the castles to Hungarian aristocrats-has now been overwritten by the blissful Slovak present. Hence, Duša exploited the visual conventions of the picturesque to express his contemporary political message.

It is interesting to compare Jeges's depiction of Beckó/Beckov from Bleeding Hungary with Duša's print of the same castle (Figure 9). Like the rest of Down the Váh, Beckov exhibits the typical characteristics of interwar wood engravings: robust contrasts, well-defined contours, and simplified forms that nevertheless possess an evocative strength. These are all features of the formal language of expressionism, and the popularity of wood engraving in interwar Central Europe was closely connected to the

\footnotetext{
${ }^{54}$ Duša, Dolu Váhom/Ritter, Roman slovenskej rieky, 5.
} 
prevalence of this modernist trend. At the same time, it was also a technique that evoked the past: the "primitivism" of medieval and early modern printmaking was embraced not only by expressionists but also by more conservative artists looking for traditional sources to renew the art of their time. ${ }^{55}$ Hence, like Jeges, the Czechoslovak artist employed a deliberate archaism, in line with the traditionalist agenda promoted in Down the Váh. Nevertheless, the formal language of the two prints could not have been more different. Jeges's etching is harmonious, made up of fine little strokes that soften its contours. Duša's engraving is composed of forceful lines and large patches of black. It shows the ruins standing on a menacingly steep cliff, its darkness set against a swirling cloud resembling a visionary baroque fresco.

The difference between the two images corresponds to the difference between their ideological contexts and between the respective mental maps they fit into. In Jeges's image, Beckó's gothic atmosphere is tamed because the castle now stands for the venerable Hungarian past rather than a thrilling horror story. Duša could, by contrast, let the gothic terror roam free. In a series that celebrated the rebirth of Slovakia from the culture of its peasants, there was no need to venerate the dilapidated old seat of a local nobleman. It could be seen as a tourist attraction known for the chilling tale told about it by the local Slovak population. Stíbor's tale was definitely still in circulation: the travel guide Columbus in der Slovakei-published in Bratislava in German, aimed at German-speaking tourists-devoted almost two pages to it. ${ }^{56}$

Similar contrasts can be observed through further comparisons. In the album Justice for Hungary!, the castles near the Vág were represented by the nineteenth-century English lithograph of Trencsén and a photograph of Árva. In the mental map promoted by the publication, they were disconnected from the Vág region and embedded into the grand narrative of Hungary's history. Although Árva was represented by a recent photograph, both places were historicized. Their Czechoslovak present was uncomfortable and not worthy of representation-even though, of course, it was the fact that they now belonged to Czechoslovakia that gave the book its raison d'être in the first place.

In Duša's Down the Váh, Trenčín looked completely different (Figure 10). The basic compositional structure of the image-the sublime old castle on top of the hill in the background, people peacefully going about their menial agricultural tasks in the foreground-was borrowed from the picturesque tradition. The ragged shape of the tree added an unsettling element. The castle was, however, integrated into a modern vision of the town, with cubic buildings and a factory chimney. With its block-like forms, the castle fits into the twentieth-century town as a standard element of the present. Interestingly, the closest precedent to this modernizing approach is the view of the same castle in the Kronprinzenwerk, which includes the modern railway bridge and-like the accompanying textpresents the castle as an integral part of the town (Figure 4). Similar to the Kronprinzenwerk, Down the Váh was taking stock of land its creators felt they possessed in the present, not lamenting historical losses like the Hungarian revisionist publications. All these possible meanings were coded into the nineteenth-century tradition of the picturesque landscape, and twentieth-century creators drew on different aspects of that tradition when presenting ideas of national territory in visual form.

\section{A Contested Site: From Dévény to Devín}

Although Hungarian and Czechoslovak attitudes toward the Slovak landscape were different, they were rooted in a shared past. In this, the final, section, an oft-depicted site will demonstrate the dynamics of cultural memory in a contested territory. Located at the western edge of the nineteenth-century Kingdom of Hungary, bordering Austria and situated near Pozsony/Prešporok/Pressburg/Bratislava, the location of Hungarian national assemblies until the mid-nineteenth century, the castle of

\footnotetext{
${ }^{55}$ On these meanings of wood engraving see Katalin Bakos, "Fametszet és illusztráció: könyv, album, mappa, sorozat 19201940,” in A modern magyar fa- és linóleummetszés (1890-1950), ed. Enikő Róka (Miskolc, 2005), 71-72.

${ }^{56}$ Leopold Wolfgang Rochowanski ed., Columbus in der Slovakei (Bratislava, 1936), 251-53. On the book see Julia Secklehner, "Artwork of the Month, April 2020: Columbus in der Slovakei by Leopold Wolfgang Rochowanski (1936)," accessed 28 Apr. 2020, https://craace.com/2020/04/28/artwork-of-the-month-april-2020-columbus-in-der-slovakei-by-leopold-wolfgang-rochowanski/.
} 


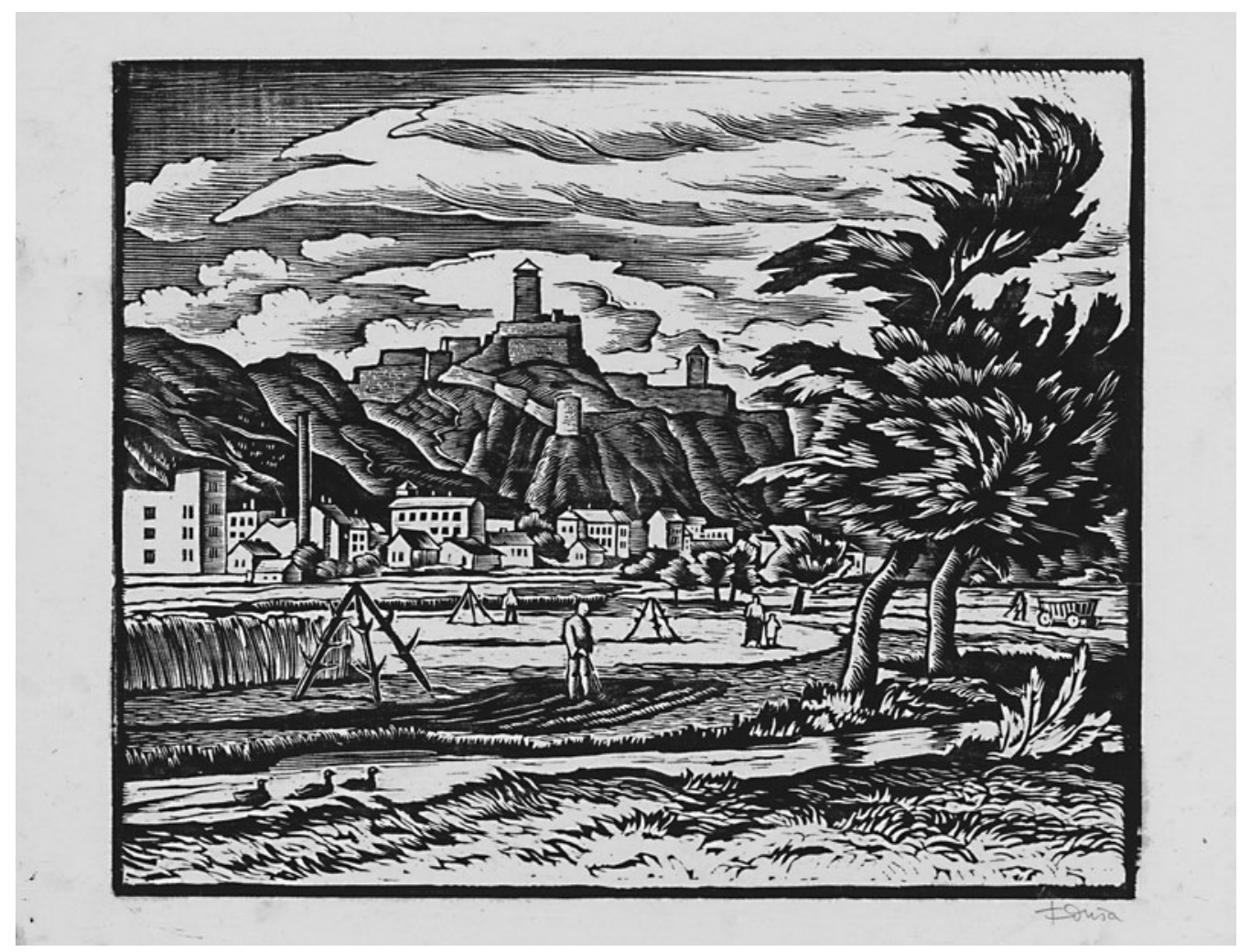

Figure 10: Ferdiš Duša, Trenčín/Trencsén/Trentschin, 1932-33, from the series Dolu Váhom, Slovak National Gallery, Bratislava, Inv. No: G 1122. Photo @ Slovenská národná galéria.

Dévény/Devín/Theben featured in both Slovak and Hungarian historical memory. Gabriela Kiliánová has extensively analyzed the significance of this memory site from its first appearances in historical narratives up to the present day, drawing on a wide range of mostly textual sources, from history writing to the popular press. ${ }^{57}$ The following pages, in turn, will examine the role of images in shaping the symbolism of the site, revealing additional meanings uniquely conveyed by the visual tradition.

As a site of memory, Devín was, perhaps, of greatest importance to Slovaks, who remembered it as a central fortress of ancient Great Moravia. For Hungarians, in turn, Dévény was a place where they had defeated the Moravians in the late ninth century. ${ }^{58}$ Due to its historicity, its symbolic location at the Austrian-Hungarian border, as well as its arresting visual qualities, Dévény was favored by landscapists in the nineteenth century. János (Johann) Hofbauer (1803-39), a native of Győr in northwestern Hungary, painted his version in the early 1830s (Figure 11). The picture includes many typical picturesque motifs: the rock and the castle in the background, fertile nature in the foreground, interestingly shaped but not menacing clouds, tiny human figures rowing their boats on the peaceful river. They are, however, less prominent than the motif that opens up the landscape toward the modern, industrialized world: an early steamship approaching from the left.

The juxtaposition of ancient ruins with fertile nature or with the human culture of the present was a standard feature of picturesque variety. In his painting of Dévény, Hofbauer took this trope to the

\footnotetext{
${ }^{57}$ Gabriela Kiliánová, "Ein Grenzmythos: Die Burg Devín,” in Heroen, Mythen, Identitäten: Die Slowakei und Österreich im Vergleich, ed. Hannes Stekl and Helena Mannová (Vienna, 2003), 49-80; Gabriela Kiliánová, Identität und Gedächtnis in der Slowakei: Die Burg Devín als Erinnerungsort (Frankfurt, 2011).

${ }^{58}$ See Kiliánová, "Ein Grenzmythos"; Kiliánová, Identität und Gedächtnis in der Slowakei, 11-56. See also Varga, The Monumental Nation, 47-72. According to Kiliánová's findings, the castle did not feature prominently in German historical memory; the local German population accepted the Hungarian narrative.
} 


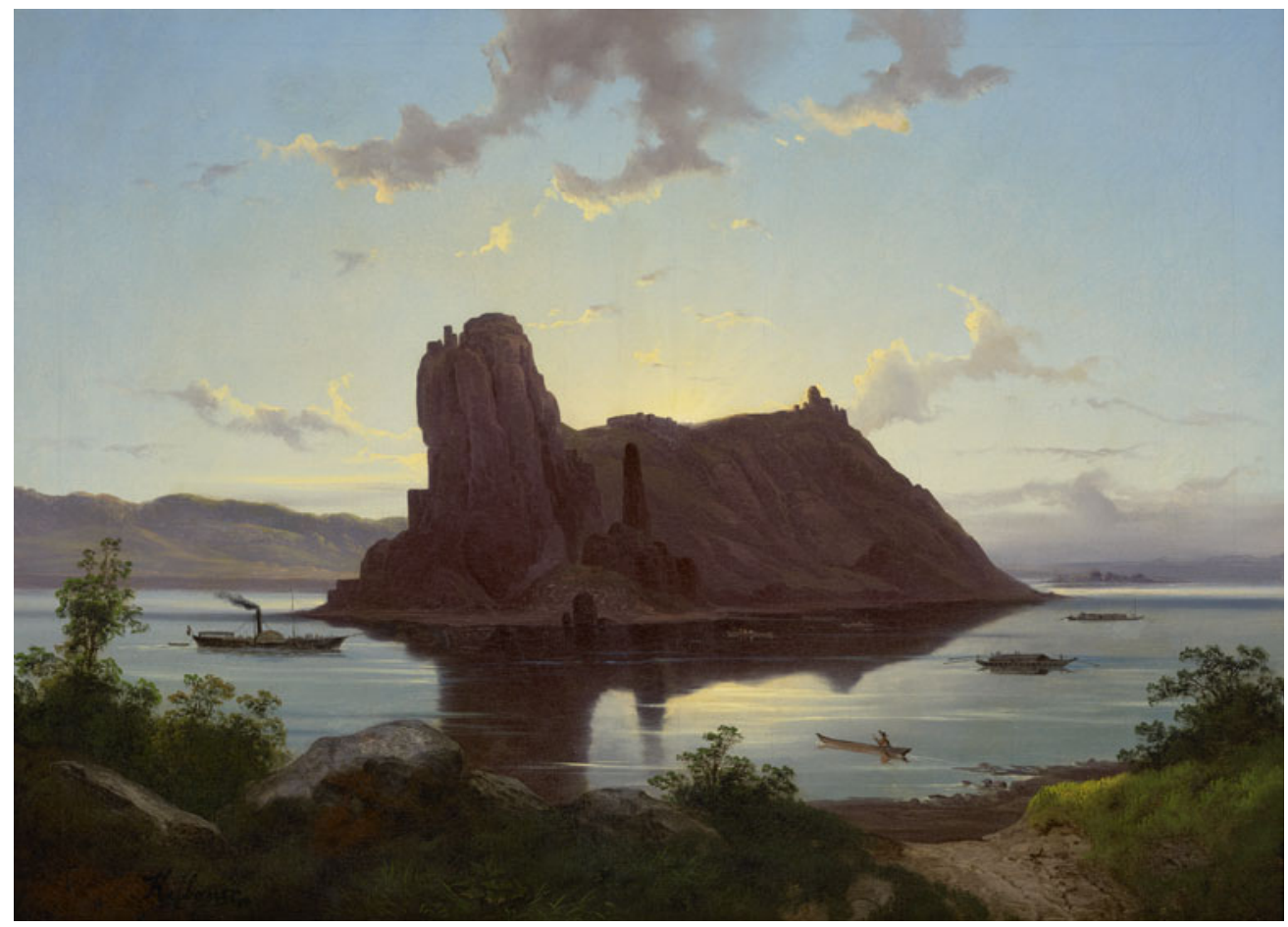

Figure 11: János Hofbauer, The Castle of Dévény/Devín/Theben, early 1830s, Hungarian National Gallery, Budapest, Inv. No: FK 8020. Photo @ Szépművészeti Múzeum / Museum of Fine Arts, 2021.

extreme by including a motif that was, at the time, shockingly modern. Following the first successful attempt in 1830, steamships had only begun to regularly cruise the Danube between Vienna and Pest in 1831, thanks to the First Danube Steamship Company, founded by two Englishmen. The contrast between old and new was the central theme of Hofbauer's painting, in which the ruined castle is barely distinguishable from the rocky hill on which it stands. The rocks dissolve into darkness because the source of light - the rising sun-is behind them. Its glow embraces the top of the rocks and glimmers on the surface of the water. A painterly effect that adds a sublime touch to the picturesque image-but it is also a visual metaphor. Hofbauer was active in the so-called Age of Reform, the period between c. 1825 and 1848, when enthusiasm for modernization and the hope for a brighter future permeated Hungary's public discourse. The most frequently used metaphor was that of a new dawn. ${ }^{59}$ Hofbauer's painting juxtaposes the ancient military virtue of the Hungarian nation with its newly acquired prowess in modern technology, enveloping them into a metaphorical sunrise. Located on a boundary between East and West, the castle of Dévény was perfectly positioned to show the arrival of an innovation from the West and the resulting sunrise in the East. The castle, the vestige of old glory, is a beautiful but ultimately no longer functional obstacle between the two worlds.

In the following decades the steamship became a recurrent motif in representations of Dévény, probably catalyzed by Hofbauer's composition, which was also disseminated in the form of prints. ${ }^{60}$ It appears in newspaper illustrations and postcards in the 1880s and 1890s, cementing the association between the ancient ruins of Dévény and modernity. Interestingly, the motif seems to have been purely visual. Reading through a number of articles on Dévény published in the late nineteenth-century Hungarian press, it is conspicuous how they omit the steamship from its history, except for

\footnotetext{
${ }^{59}$ On this trope in pre-1850 Hungarian culture see Béla Zolnai, A magyar biedermeier (Budapest, 1940).

${ }^{60}$ Carl Gerolds and Franz Josef Sandmann after János Hofbauer, Devín, c. $1840-50$, lithograph on paper, $19.5 \times 26 \mathrm{~cm}$, Slovak National Gallery, Bratislava, Inv. No G 8162.
} 


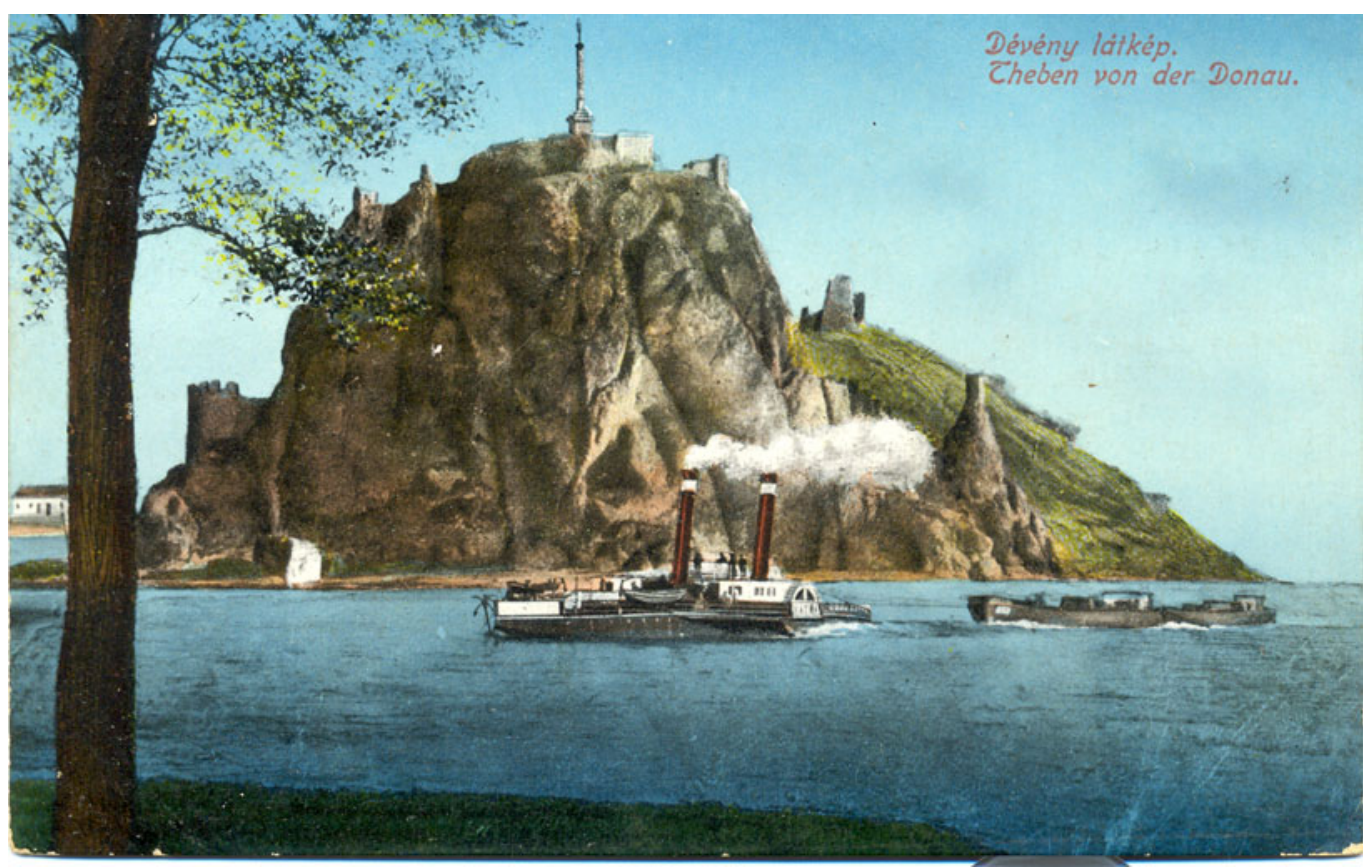

Figure 12: Postcard showing Dévény/Devín/Theben with the Árpád monument, c. 1910. Forum Minority Research Institute, Hungarian Databank in Slovakia, Postcard Collection, Inv. No: 4221. Photo @ Forum Minority Research Institute.

mentioning it as a means of transport that helps access the landmark. More important than the steamship was to refute Slovak claims that Devín had once been the seat of the emperor of Great Moravia. ${ }^{61}$ In the constructions of historical memory that formed part of Hungarian nation-building in the nineteenth century, Dévény was to feature as a key location of the conquest, and competing Slovak narratives needed to be played down.

It was to this end that the Hungarian government made a drastic intervention into the Dévény landscape in 1896. As part of the Millennium Celebrations, seven monuments were erected across the country to mark locations significant to the history of the conquest, but also to remind the local non-Magyar population of Magyar hegemony. The monument erected on the Dévény cliff was a tall column with the statue of an ancient Hungarian warrior, identified in the press as Chieftain Árpád, leader of the conquest. ${ }^{62}$ In the next twenty years, the column was undoubtedly the most important element in visual and textual representations of Dévény. The steamship, sometimes there, sometimes not, was part of the picturesque effect, its once cutting-edge modernity tamed by the decades that had passed since 1830. The Árpád statue, however, added the crucial values now favored by the increasingly ethnonationalist mainstream in Hungarian politics (Figure 12).

The first steamship to cruise the Danube passed many scenic and historically significant locations on its way from Vienna to Pest, but its image only became imprinted onto the Dévény landscape in (art) historical memory. Besides the striking contrast between the ancient ruins and the modern means of transport, Dévény offered something more: as the westernmost point of Hungary, it helped conceptualize the opposition between old and modern as an opposition between East and West. Self-identification as an "Eastern" culture was an important component of Hungarian nationalism throughout the nineteenth century, but the pride associated with these Eastern origins, conceptualized as wild and exotic, could coexist with acknowledging the necessity of taming them by adopting

\footnotetext{
${ }^{61}$ See e.g., A Csallóközi utiképek irója, “Fehérhegységi utiképek," Vasárnapi Ujság, 13 May 1860, pp. 232-33. On competing Slovak and Hungarian narratives in the nineteenth century see Kiliánová, Identität und Gedächtnis in der Slowakei, 43-56.

${ }^{62}$ On the monument at Dévény and the whole project see Varga, The Monumental Nation, esp. 177-81. On the inauguration of the column see also Kiliánová, Identität und Gedächtnis in der Slowakei, 51-54.
} 
Western ideas of social and industrial progress. In the Age of Reform, this was a recurrent theme, and one of its proponents was Count István Széchenyi (1791-1860), a committed Anglophile who-among other innovations-had also championed the steamship. Representations of Dévény were not simply about a specific site, they also located that site-and hence Hungary-between East and West, both in a geographical and a metaphorical sense.

After World War I, Dévény became part of Czechoslovakia with the rest of former Northern Hungary. On 12 January 1921, four unnamed men toppled the Árpád column, despite protests from the mostly German-speaking locals. ${ }^{63}$ In interwar Czechoslovakia, Devín as a memory site became crucial for promoting the idea that, due to its ancient Slavic roots, the region rightfully belonged to the Slavs; whether that meant Czechs and Slovaks or just Slovaks constituted a subdued conflict that bubbled up increasingly as the years passed. Trianon undoubtedly marked a turning point in how the site was employed in memory politics. But in the mental maps of the inhabitants of Central Europe, it also retained its old associations, adapting them to new realities.

Although the Árpád monument had been demolished in 1921, every mention of the location in the interwar Hungarian press included a reference to it. It was like an amputated limb that still felt painful. The references were, of course, tinted by the political stances of the papers. In his article quoted earlier, the liberal journalist Árpád Pásztor argued for a confederation, or at least trade agreement between the states along the Danube, and urged his fellow Hungarians to accept the changes symbolized by the transformed face of the Dévény landscape. ${ }^{64}$ Although similarly liberal, the daily Ujság delved deeper into sentimental revisionism: "Today a Czech flag flies in the place of the Árpád monument; one long, aching glance, a silent greeting, and we are at home, in Greater Hungary." ${ }^{\prime 65}$ The announcement of a Danube cruise organized by the right-wing Magyarság was less poetic and more confrontational: "Where the Danube and the Morava meet, on a rock stands what remains of Dévény castle. The Árpád statue that used to stand on top of the rock has been demolished by the Czech invaders." ${ }^{\prime 66}$ Despite the differences in tone and viewpoint, the articles demonstrate the position of Dévény in Hungarian mental maps: it was a place that evoked the past and made recent geopolitical changes particularly tangible through the memory of the demolished monument. It was also special because it marked the old border of the kingdom.

Greater Hungary was a place that lived on in memory, detached from the actual political map of Central Europe. Sometimes, in the same way as in the album Justice for Hungary!, it was possible to collapse its cultural values, its historical meanings, into the smaller space of the new Hungary. Discussing the new bridge that was about to be constructed across the Danube in Budapest, a journalist in 1929 stated: "This bridge will have to be named Árpád Bridge. Before Trianon the ancient castle of Dévény was the Porta Hungarica, now the gigantic pillar of this bridge will be the symbol of the Hungarian land in the eyes of foreigners arriving on the Danube." ${ }^{97}$ The pillar should, said the journalist, be adorned with a statue of Ârpád, which could replace the destroyed monument.

To these Hungarian commentators, Dévény as a memory site encapsulated, more poignantly than any of the other locations discussed in this article, the radical political changes that transformed the region after 1918. The flagpole, visible in the present, the Árpád column, no longer there but still constantly evoked, and finally an older, even more persistent ghost-the idea of the Porta Hungarica-were all enmeshed in interwar Hungarian cultural memory. Dévény evoked layers of the past. This view of the past as inscribed into the landscape was not, however, unique to the Hungarian perspective. Its most suggestive representation appears in a 1937 print by Imro Weiner-Král' (1901-78), a Bratislava-based Slovak-Hungarian-Jewish artist who, like many of his contemporaries, embodied the entangled nature of national identities in Slovakia that nationalists on all sides were trying to erase (Figure 13).

By 1937, Weiner-Král' had spent years in Paris and in Berlin, returning to Bratislava the year before. His depiction of Devín is part of a series of woodcuts he made of Bratislava. The prints were published

\footnotetext{
${ }^{63}$ Kiliánová, Identität und Gedächtnis in der Slowakei, 60-62.

${ }^{64}$ Pásztor, "A cseh Dunán," 4.

65“Magyar vándorevezős tura Passau-Budapest 1930,” Ujság, 12 Aug. 1930, p. 12.

66“Két csodaszép dunai társasutazást rendezünk...," Magyarság, 21 Apr. 1935, p. 25.

${ }^{67}$ Edgár Palóczi, "Budapest legelhagyatottabb városrésze: Óbuda, a klasszikus emlékek földje,” Nemzeti Újság, 5 May 1929 , p. 11 .
} 


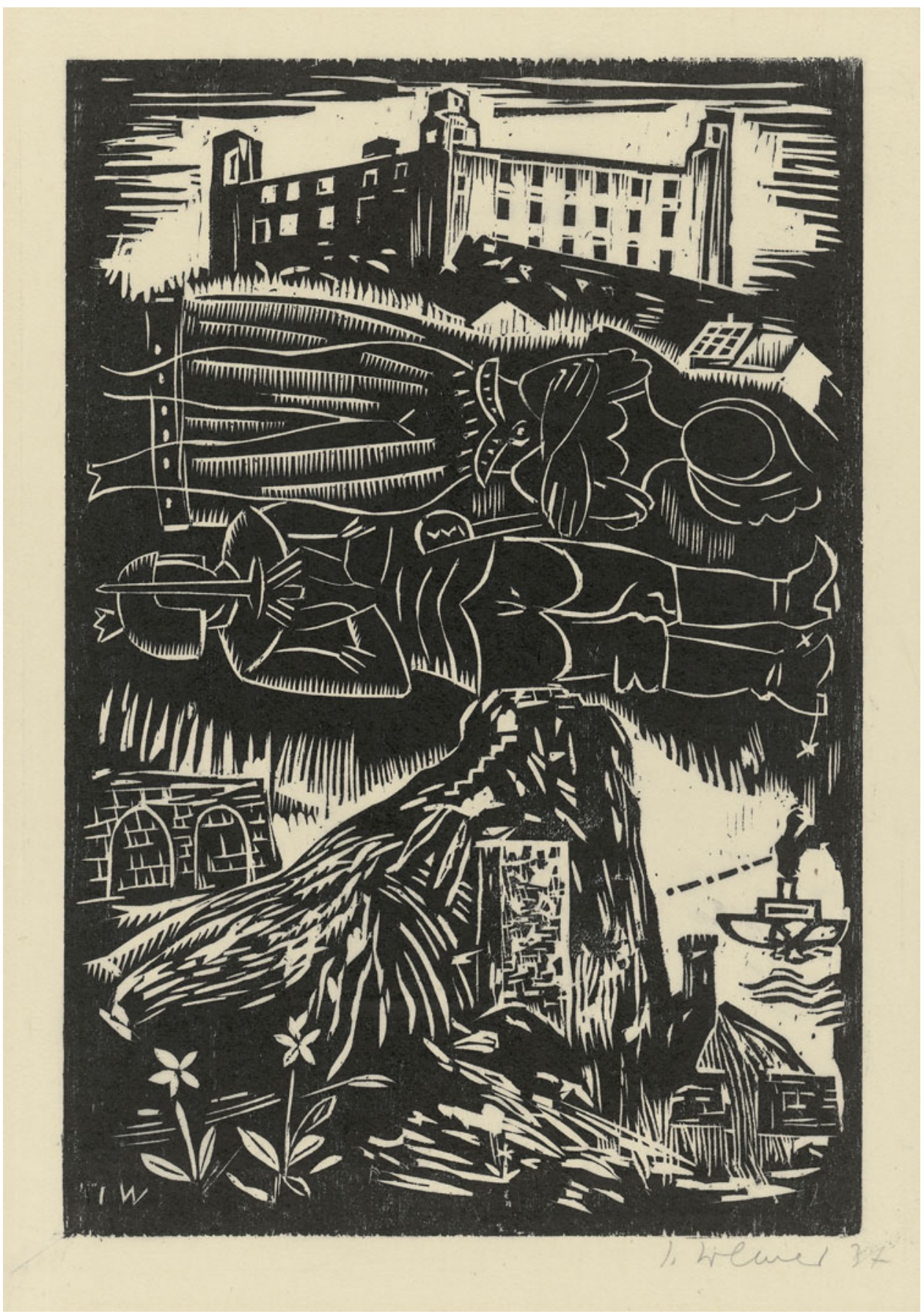

Figure 13: Imro Weiner-Král, Devín/Dévény/Theben, 1937, Slovak National Gallery, Bratislava, Inv. No: G 985. Photo @ Slovenská národná galéria.

separately and their original order is not clear, although the existence of a front page suggests that they had been conceived to form an album. ${ }^{68}$ They all show Weiner-Král's preoccupation with surrealism and penchant for the grotesque, bringing together the naive tone of fairytales with depictions of

\footnotetext{
${ }^{68}$ Marian Váross, Imro Weiner-Král' (Bratislava, 1963), 38; Dagmar Snenská and Alma Münzová, Imro Weiner-Král’ (Bratislava, 2001), 30.
} 
Bratislava nightlife, peasants in folk dress with businessmen smoking cigars, and the old monuments of the city with its modern architecture.

The image showing Devín fits integrally into the series. Like many other prints from the cycle, its composition brings together different themes by arranging them in horizontal layers. The silhouette of Bratislava castle at the top is also a recurring motif. There is nevertheless one aspect that makes the picture of Devín stand out. The majority of sheets in the Bratislava cycle depict the city's present, offering both affectionate insight and social critique; indeed, it is this aspect of the work that literature on the artist highlights as its seminal feature. ${ }^{69}$ The image of Devín, however, focuses on history. This is expressed by its alternative titles: the Slovak National Gallery records it both as Devin and as The Past (Minulost), while in the most recent monograph it is reproduced as Scene of Action (Dejisko). ${ }^{70}$ The last title is perhaps the most fitting: the image presents Bratislava and nearby Devín as a stage on which historical events had taken place throughout the centuries, witnessed by the two ancient castles. The spatial dimension of history precedes the chronological one.

In the upper half of the composition, beneath Bratislava castle, lie a medieval knight and lady. They represent the people of the past, their fights and loves, and their former vigorous existence. Once flesh and blood, they are now reduced to faint silhouettes, like cutout dolls. Devín is depicted in the bottom half of the image, and to the right floats the steamship, drawn up in a few simple lines, as if it were a child's idea of a ship. More than a hundred years had passed since Hofbauer's painting, and the steamship was no longer an example of the latest technological advances. Rather than providing a forceful contrast between old and new, Weiner-Král's print used Bratislava and Devín to show the layers of history that the (Czecho)Slovakia of his time was built on, emphasizing this idea through the layered composition. Hence, Weiner-Král' exposed the historical symbolism that had always been inherent to picturesque landscapes, while rejecting picturesque compositional effects in favor of a radically modern, comic-book-like layout. Through one picturesque motif-the flowers in the foreground-he included a playful nod to the tradition he was dismantling.

The question of whether to present Bratislava and its environs as ancient or modern was one that permeated the memory politics of interwar Czechoslovakia. On the one hand, the state aimed to present itself as quintessentially modern, and hence superior to the Austro-Hungarian past. On the other hand, to assert the legitimacy of Czechoslovak territorial claims over Hungarian ones, proving the ancientness of Slavic culture in Slovakia seemed paramount. This was a duality that manifested itself in the tourist guides of the period, which celebrated the modernity of Bratislava by showcasing its new architecture while also building up a teleological narrative that constructed a line of logical development between the Great Moravia of the ninth century and the glorious Czechoslovak future. ${ }^{71}$

In his cheerful oil painting of 1930, the Slovak modernist L'udovit Fulla (1902-80) reduced the castle to geometric forms that make it indistinguishable from a modern building, completely obliterating its ancientness (Figure 14). The shapes are delineated by strict, straight lines, but the paint is laid on freely with loose brushstrokes. The main colors-white, red, and blue-echo the colors of the Czechoslovak flag. On the right-hand side of the composition, an airplane is flying up toward the castle. Ivan Gerát has drawn attention to the political message of the painting, neglected in previous, formalist discussions that had emphasized the modernist visual language and claimed that the choice of subject matter was completely arbitrary. ${ }^{72}$ In Gerát's analysis, the modernist formal idiom enforces the political meaning. To Slovaks, Devín was the symbol of a glorious Slavic past. In Fulla's picture, that past was resurrected, and also immediately superseded by the Czechoslovak state and its modernity. An image that reimagines the ancient as modern and complements it with a symbol of technical

\footnotetext{
${ }^{69}$ Snenská and Münzová, Imro Weiner-Král', 30.

${ }^{70}$ For the SNG titles see SNG Inv. nos G 985 and G 3010; for Scene of Action see Snenská and Münzová, Imro Weiner-Král', 30.

${ }^{71}$ See Jozef Tancer, "Die Geburt Bratislavas auf den Seiten der lokalen Stadtführer 1918-1945," in Zwischen Exotik und Vertrautem, 225-30.

${ }^{72}$ Ivan Gerát, “Tschechoslowakische Staatssymbolik und slowakische Nationalmythen im Werk von L'udovít Fulla (19021980)," in Neue Staaten - Neue Bilder: Visuelle Kultur im Dienst staatlicher Selbstdarstellung in Zentral- und Osteuropa seit 1918, ed. Arnold Bartetzky et al. (Cologne, 2005), 76-86. For a formalist discussion of the painting see Ján Abelovský, “Slovenské kontexty L’udovíta Fullu," in L'udovit Fulla, ed. Katerína Bajcurová (Bratislava, 2002), 176.
} 


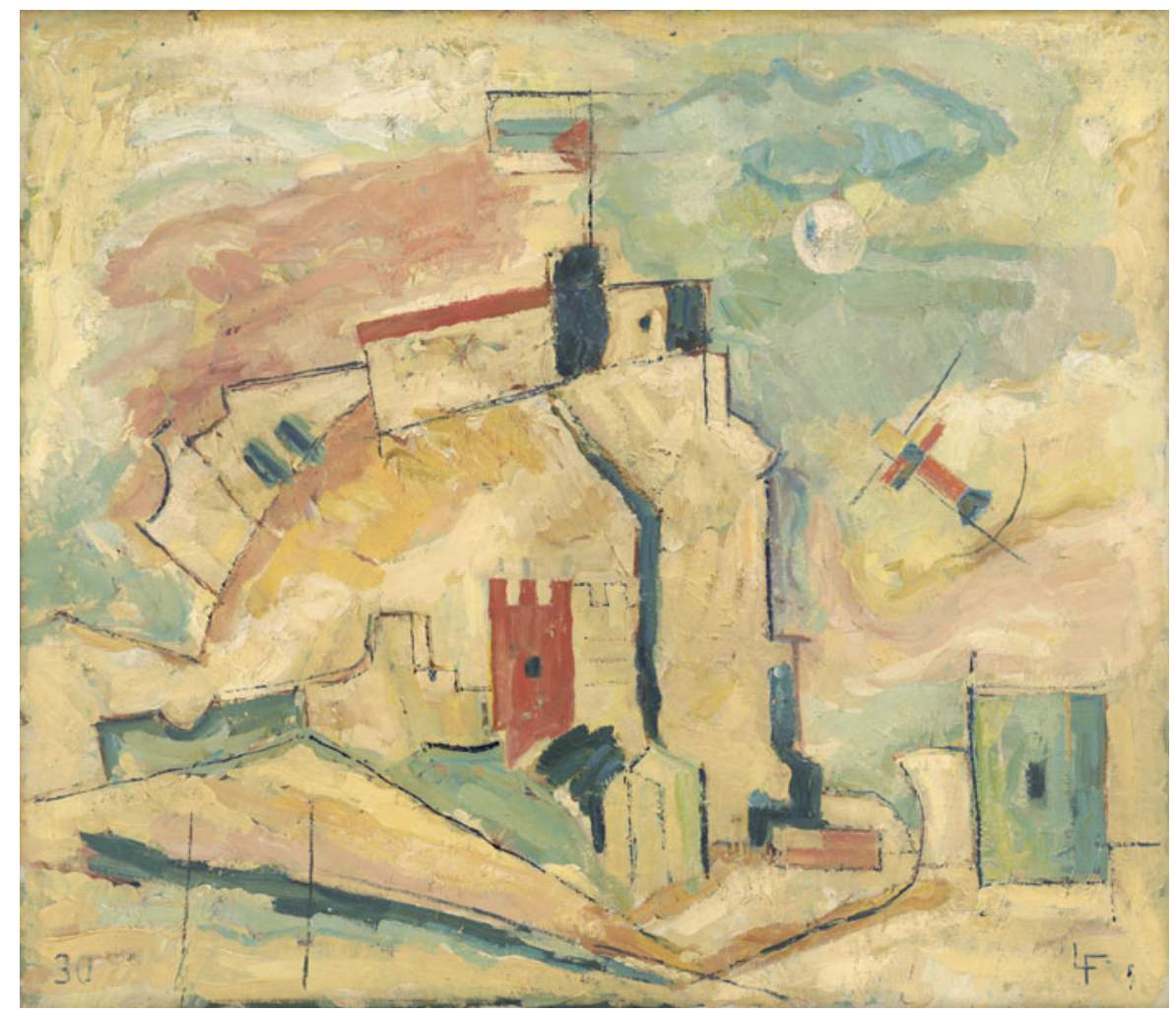

Figure 14: L’udovit Fulla, Devín, 1930, Slovak National Gallery, Bratislava, Inv. No: O 1927. Photo @ Slovenská národná galéria.

progress - the airplane-can safely be read as a visualization of this state ideology. This interpretation is supported by the prominent representation of a flag with national colors, flying from the flagpole that was, as we know from the interwar Hungarian press, seen as replacing the Árpád monument.

Only ten years had passed between the Treaty of Trianon and Fulla's painting, but Hungarian Dévény with its ancient warrior and Czechoslovak Devín with its dynamic modernism seem to be eons apart. Yet, looking further back into the past, the continuities are there, and they are strikingly obvious. Hofbauer's steamship, in 1830, and Fulla's plane, in 1930, are expressions of the same idea: the progressive present juxtaposed with the ancient past. Did Fulla know Hofbauer's painting? He may have, but he did not need to. The idea that Devín was a gateway to the West was well known, and the broader idea that the "West" symbolized social and intellectual progress was deeply rooted in Central European culture. In a well-known poem Góg és Magóg fia vagyok én (I am the son of Góg and Magóg) published in 1906, the Hungarian modernist poet Endre Ady (1877-1919) described himself as an ancient Magyar warrior bursting into the country at Dévény-that is, from the West-bringing new, modern songs that could renew Hungarian culture while retaining its Hungarian character. Subsequently, in Czechoslovakia the idea that the country belonged to the West rather than the East in terms of culture was an important tenet of official ideology and served to underpin the Western European orientation of Masaryk's politics. ${ }^{73}$ Their perceived position between East and West was an important element in the identity constructions, and hence mental maps of all Central European cultures before and after 1918. The example of Dévény/Devín shows how these ideas could coalesce in the cultural memories associated with one specific place, and

\footnotetext{
${ }^{73}$ On this and further on the way nineteenth- and twentieth-century Czech mental maps positioned the nation between East and West see Peter Bugge, “Land und Volk' - oder: Wo liegt Böhmen?” Geschichte und Gesellschaft 28, no. 3 (2002): 404-34, esp. $414-17$.
} 
how images and texts jointly contributed to the formation of such sites of memory: geographically precise, yet abstract, symbolic, and immaterial.

\section{Conclusion}

The idea of an organic connection between landscape, nation, and history emerged in the nineteenth century but resonated, with serious consequences, in the twentieth. This article has analyzed a number of examples in which landscape imagery played a role in shaping and promoting this mindset. The diverse ways in which older pictorial traditions were employed and transformed in these images highlight the complexities of interwar memory politics. Approaches to the past and its afterlives in the present were manifold, and exploring them in relation to each other reveals the dynamics of cultural memory: the clashes, but also surprising correspondences between opposing viewpoints, as well as their inner contradictions. In this vein, the study has highlighted a few of the myriads of overlapping mental maps that emerged in this tumultuous time. Bleeding Hungary exemplified a Hungarian revisionist approach that construed the "lost" territories as a coveted area of extraordinary value. A decade later, Justice for Hungary! set out to demonstrate the organic territorial integrity of Greater Hungary while also providing a framework for a provisional mental map that packed a wider array of Hungarian historical memories into post-Trianon Hungary. In these publications, locations in Slovakia figured as vessels of Hungarian history, and hence their ancientness was emphasized. By contrast, from a Czechoslovak point of view they were places where something new could be built on the vestiges of the old. Finally, the case study of Dévény/Devín highlights how old memories persisted in rival mental maps shaped by opposing political agendas.

The study of cultural memory through overlapping mental maps helps extricate the study of memory politics from a national context. Images of landscapes constituted one important medium that made these maps seem more real and tangible. In the case of Central Europe, their study demonstrates with particular clarity how differing interpretations of a shared past can evolve into diametrically opposite points of view, even if they are colored by transnational cultural tropes stemming from shared traditions. From a historian's detached perspective, these shared traditions offer intriguing connections to explore, but in the political arena these similarities, these undeniable connections, can also make conflicts more bitter. Examining competing constructions of history in relation to geographical space helps to see the role of shared traditions in its ambivalence. As a methodology, it offers novel insight into the relationship between territorial conflict and cultural memory in Central Europe and elsewhere.

Nóra Veszprémi is a research fellow at Masaryk University in Brno, where she is involved in the European Research Council-funded project "Continuity/Rupture: Art and Architecture in Central Europe 1918-1939." She has previously worked as a research fellow at the University of Birmingham, a lecturer at Eötvös Loránd University in Budapest, and a curator at the Hungarian National Gallery. She has coauthored two monographs on museums in Austria-Hungary and published a book on Hungarian romanticism, as well as a number of essays on Central European nineteenth- and twentieth-century art history.

Cite this article: Veszprémi N (2021). Whose Landscape Is It? Remapping Memory and History in Interwar Central Europe. Austrian History Yearbook 52, 227-252. https://doi.org/10.1017/S0067237821000102 